\title{
Resveratrol, Metabolic Syndrome, and Gut Microbiota
}

\author{
Alice Chaplin ${ }^{1, *(\mathbb{D})}$, Christian Carpéné ${ }^{2}$ and Josep Mercader ${ }^{3,4, *(\mathbb{D})}$ \\ 1 Cardiovascular Research Institute, School of Medicine, Case Western Reserve University, Cleveland, \\ OH 44106, USA \\ 2 INSERM U1048, Institute of Metabolic and Cardiovascular Diseases (I2MC) and University Paul Sabatier, \\ 31432 Toulouse, France; christian.carpene@inserm.fr \\ 3 Department of Fundamental Biology and Health Sciences, University of the Balearic Islands, \\ 07122 Palma, Spain \\ 4 Balearic Islands Health Research Institute (IdISBa), 07122 Palma, Spain \\ * Correspondence: amc315@case.edu (A.C.); josep.mercader@uib.es (J.M.); \\ Tel: +1-216-258-8385 (A.C.); +34-971-172-009 (J.M.)
}

Received: 15 October 2018; Accepted: 29 October 2018; Published: 3 November 2018 updates

\begin{abstract}
Resveratrol is a polyphenol which has been shown to have beneficial effects on metabolic syndrome-related alterations in experimental animals, including glucose and lipid homeostasis improvement and a reduction in fat mass, blood pressure, low-grade inflammation, and oxidative stress. Clinical trials have been carried out to address its potential; however, results are still inconclusive. Even though resveratrol is partly metabolized by gut microbiota, the relevance of this "forgotten organ" had not been widely considered. However, in the past few years, data has emerged suggesting that the therapeutic potential of this compound may be due to its interaction with gut microbiota, reporting changes in bacterial composition associated with beneficial metabolic outcomes. Even though data is still scarce and for the most part observational, it is promising nevertheless, suggesting that resveratrol supplementation could be a useful tool for the treatment of metabolic syndrome and its associated conditions.
\end{abstract}

Keywords: resveratrol; gut microbiota; metabolic syndrome

\section{Introduction}

In obese states, insulin resistance and inflammation are the underlying causes of the metabolic syndrome, and together with high blood triglycerides, altered cholesterol levels, glucose intolerance and hypertension, they greatly increase the risk of type 2 diabetes and cardiovascular disease [1]. Currently, the main treatments for metabolic syndrome are weight loss and physical activity; however, there is also evidence that pharmacotherapy (insulin sensitizers, statins, angiotensin-converting enzyme inhibitors) and, more recently, nutritional strategies could be beneficial [2]. Within this context, resveratrol, a natural phytochemical widely found in plants, fruits, and red wine, presents itself as a potential candidate, due to the recent observations in various animal models and human studies of its beneficial effects in terms of glucose and lipid homeostasis and reduced body fat accumulation [3-6]. It is known as a phytoalexin because of its ability to inhibit the progress of certain infections, and is one of the components of red wine believed to contribute to the French Paradox, which refers to a low prevalence of ischemic heart disease in populations with high intakes of saturated fat [7]. Furthermore, it has been demonstrated that resveratrol mimics calorie restriction effects through sirtuin 1 (SIRT1) activation, and thus extends the lifespan in simple organisms and prevents the deleterious effects of excess caloric intake in rodents, such as insulin resistance and body 
fat accumulation $[4,8]$. In humans, however, the effectiveness towards the treatment of metabolic syndrome has been reported to be in some cases lower than in experimental animals [9]. In addition, discrepancies and inconsistencies have been observed in clinical trials, which can be explained by differences regarding the form of supplementation and the characteristics of the treated individuals, such as age, sex, presence of single nucleotide polymorphisms, presence of metabolic disturbances, and gut microbiota composition. Considering resveratrol is metabolized by gut microbiota $[10,11]$ and that it can influence its composition [12], the interplay between this stilbenoid and the host microbiota may strongly influence treatment efficiency, by either increasing its bioavailability, producing certain metabolites, or even by promoting the growth of specific bacteria. Thus, the resveratrol/microbiota interaction is a key element in the effectiveness of the treatment of metabolic syndrome. In this review, we aim to discuss the current knowledge regarding the effects of resveratrol on metabolic syndrome alterations and on gut microbiota and also try to determine how such interactions could modulate the beneficial effects of this phytochemical.

\section{Resveratrol Occurrence, Absorption, Metabolism, and Bioavailability}

Resveratrol (3,5,4'-trihydroxy-trans-stilbene) is a natural phytochemical widely found in its trans isomer form in various plants, such as Polygonum cuspidatum, in fruits, including grapes and berries, peanuts, and in red wine $[13,14]$. It is a polyphenolic compound of low molecular weight that belongs to the stilbenoid family of polyphenolic compounds (hydroxylated derivatives of stilbene based on a $\mathrm{C}_{6}-\mathrm{C}_{2}-\mathrm{C}_{6}$ polyphenolic structure). Resveratrol naturally occurs in these sources mainly in its glycosylated form, known as piceid and polydatin (3,4',5-trihydroxy-stilbene-3- $\beta$-mono-D-glucoside). Its use as a nutraceutical has been studied in both animal and human models, including clinical trials, in the context of obesity, metabolic syndrome, heart disease, and cancer, among others; however, to date, there are no specific recommendations concerning dosage and length of supplementation.

Upon ingestion, resveratrol or its precursors travel through the gastrointestinal tract, and it is estimated that around $70 \%$ of the intake of resveratrol is absorbed [13]. In the intestine, resveratrol binds to several nutrients, such as proteins, and the solubility of these will influence its absorption or elimination in feces [13]. Resveratrol absorption occurs by passive diffusion or by forming complexes with intestinal membrane transporters, including integrins. Free resveratrol circulates in the bloodstream bound to lipoproteins and albumin. However, the free form of resveratrol is found at very low levels in the bloodstream due to extensive glucuronidation in the liver and intestine and sulfation in the liver, thereby decreasing its bioavailability [14]. Hence, the major circulating forms of resveratrol are glucuronide (trans-resveratrol-3-glucoronide, trans-resveratrol-4'-glucuronide) and sulfate (trans-resveratrol-3-sulfate, trans-resveratrol-3,4'-disulfate, trans-resveratrol-3,5-disulfate) conjugate metabolites [13]. Likewise, resveratrol-3-sulfate and resveratrol-3-glucuronide are detected in target organs, such as in the liver, adipose tissue or the heart, after oral administration $[15,16]$.

Besides resveratrol conjugates, other resveratrol derivatives are also detected in target tissues, such as piceatannol and dihydroresveratrol $[17,18]$. The occurrence of piceatannol $\left(3,3^{\prime}, 4,5^{\prime}\right.$-tetrahydroxy-trans-stilbene) results from resveratrol hydroxylation in the liver by cytochrome P450 [18] and stands out due to its potentially beneficial effect on the metabolic syndrome [19]. It is a more stable stilbenoid that also naturally occurs in diverse plants. Dihydroresveratrol, synthesized by gut bacteria, together with free resveratrol, are detected in tissues after sustained resveratrol administration, whereas glucuronide and sulfate are the main resveratrol metabolites detected in tissues after an acute administration of resveratrol [17]. Therefore, the bioavailability of resveratrol and its metabolites largely differs on whether the administration is acute or sustained. In addition, the bioavailability of resveratrol and its metabolites is dose-dependent $[15,16]$.

In turn, free resveratrol can be synthesized back from its sulfate and glucuronide derivatives by ubiquitously expressed sulfatase and $\beta$-glucuronidase [13]. Moreover, resveratrol metabolites can return to the small intestine through the bile enterohepatic transport. So far, up to 21 resveratrol metabolites have been identified in human urine after moderate consumption of red wine for 
28 days [20], and it has been observed that some of these metabolites are by-products of gut microbial metabolism.

\section{Impact of Gut Microbiota on Resveratrol Metabolism}

The fact that the gut microbiota is highly responsible for metabolizing resveratrol has been known for some time; however, the importance of this process and of the metabolites and other by-products derived from this is only starting to gain relevance. As illustrated in Figure 1, the gut microbiota actively participates in resveratrol metabolism by increasing its availability from resveratrol precursors and producing resveratrol derivatives.

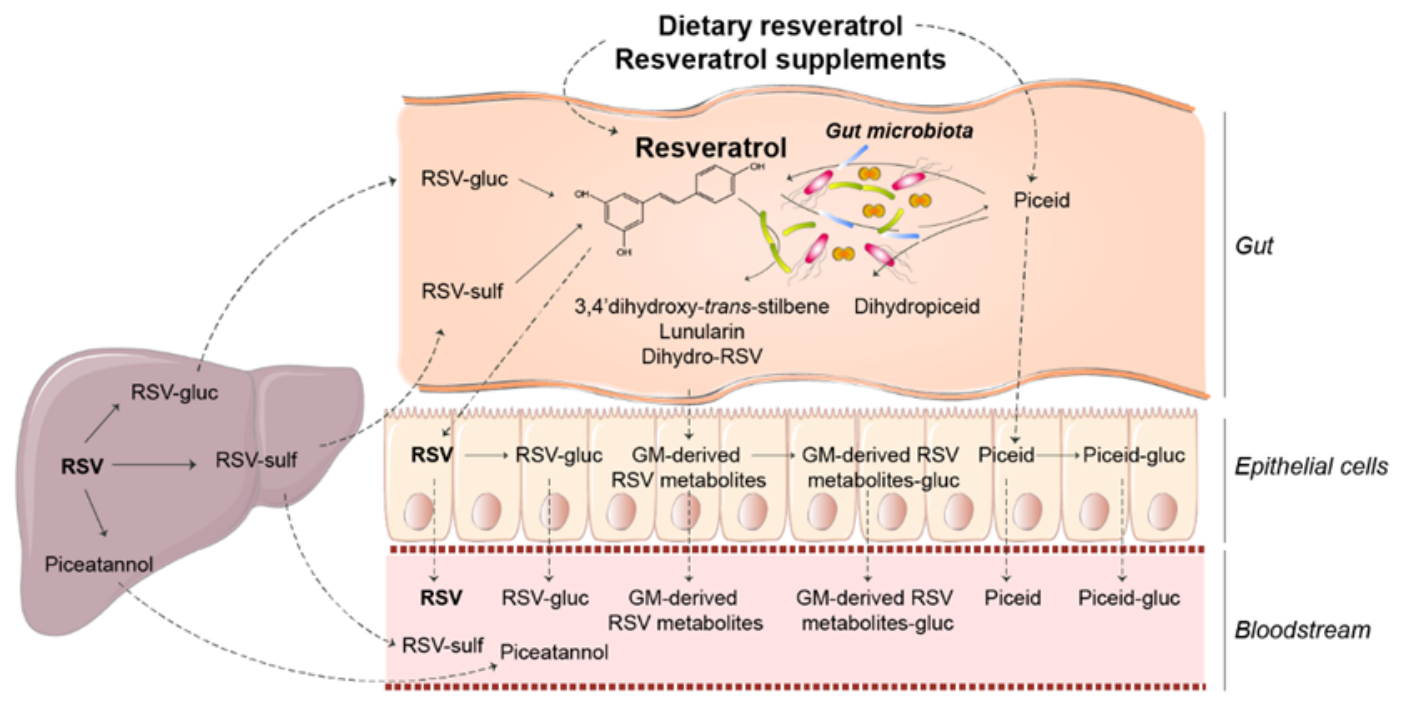

Figure 1. Overview of the metabolism of resveratrol and the impact of gut microbiota. Upon intake, RSV and RSV precursors enter the gut and are partly metabolised by gut microbiota to produce particular RSV derivatives and RSV. Free RSV, RSV precursors and microbiota-derived RSV metabolites are conjugated in the intestine and liver, from where conjugated forms can return to the intestine. In the liver, RSV is metabolised to piceatannol, which can be released into the bloodstream, and delivered to target tissues together with RSV, RSV precursors, microbiota-derived RSV metabolites and their respective conjugate forms. RSV, resveratrol; gluc, glucuronides; sulf, sulfates.

Gut bacteria metabolize resveratrol precursors to resveratrol, thereby increasing its bioavailability [14,21]. In particular, gut bacteria hydrolyze the glucoside moieties of plant glycosydes, such as the resveratrol precursor piceid, and thus externalize their aglycones. Bifidobacteria infantis and Lactobacillus acidophilus are two bacteria responsible for resveratrol production from piceid [11,21,22]. In turn, resveratrol can be glycosylated in the gut to produce piceid again. Piceid is conjugated to piceid glucuronide, and can be absorbed in both its free form, and most abundantly, in its conjugated form [23].

On the other hand, gut bacteria metabolize resveratrol and its precursors, resulting in certain resveratrol derivatives. Dihydroresveratrol was the first derivative identified, which is produced by Slackia equolifaciens and Adlercreutzia equolifaciens, followed by two other bacterial trans-resveratrol metabolites, 3,4'-dihydroxy-trans-stilbene and 3,4'-dihydroxybibenzyl (lunularin) [10]. Gut bacteria also metabolize piceid to produce dihydropiceid and dihydroresveratrol [22]. As resveratrol, gut bacteria-derived resveratrol derivatives are also conjugated to its glucuronide forms.

Furthermore, higher concentrations of dihydroresveratrol glucuronides than resveratrol glucuronides and glucosides have been found in human plasma and urine after the intake of a grape extract or red wine [23]. In tissues of rats receiving resveratrol, dihydroresveratrol glucuronide is also detected in the liver, whereas dihydroresveratrol sulfate is detected in the liver and adipose tissue [16]. 
The amount of dihydroresveratrol sulfate in the liver is remarkably higher than that of resveratrol sulfate. These observations highlight the importance of gut microbiota in resveratrol metabolism, particularly in producing specific resveratrol derivatives in significant amounts.

\section{Effect of Resveratrol on Metabolic Syndrome}

Metabolic syndrome is a cluster of a least three of the five following metabolic alterations: Central obesity, high blood glucose, high blood pressure, high serum triglycerides, and low serum high-density lipoprotein (HDL), the presence of which increases the risk of developing cardiovascular disease and type 2 diabetes [1]. Here, we describe the potential effect of resveratrol supplementation on each metabolic alteration and review the clinical trials that analyze the effects on them. It is important to note that there are still many discrepant and inconsistent results in human studies and it is clear that further research needs to be carried out to further understand the effect of resveratrol on metabolic syndrome.

\subsection{Fat Accumulation}

Over a decade ago, it was discovered that resveratrol can reduce diet-induced obesity through SIRT1 activation, generating high expectations as a potential anti-obesity molecule; since then, this effect has been shown in both mice and rats [4,8,24-26]. SIRT1 activation is of interest because it deacetylates and activates peroxisome proliferator-activated receptor (PPAR) $\gamma$ coactivator $1 \alpha$ [4], which controls mitochondrial biogenesis and function. Furthermore, it triggers lipolysis and loss of fat by repressing PPAR $\gamma$ in adipocytes [27]. Resveratrol also acts by inhibiting cAMP-specific phosphodiesterases, leading to elevated cyclic adenosine monophosphate levels, which in turn activate adenosine monophosphate-activated protein kinase (AMPK) [28]. Other anti-lipogenic mechanisms of action have been described, including the upregulation of certain microRNAs by resveratrol, which leads to the inhibition of lipogenesis in white adipose tissue [29].

\subsubsection{Resveratrol and Adipose Depot Extension}

Since the discovery of its actions on SIRT1, many other studies have been carried out to determine the potential of resveratrol in the treatment of obesity. Studies carried out in cell systems so far have shown that the anti-obesity effect of resveratrol is attributed to its actions on (1) pre-adipocytes, including the induction of apoptosis and the inhibition of proliferation and differentiation [30,31]; (2) mature white adipocytes, including the activation of lipolysis, inhibition of de novo lipogenesis, and promotion of brown adipocyte features [30,32-35]; and (3) brown adipocytes, in which the expression of the uncoupling protein-1 and typical brown-phenotype genes are induced [36]. Studies in rodents show that the resveratrol-induced reduction in fat mass is partly explained by both the activation of lipolysis through the adipose triglyceride lipase, and the inhibition of de novo lipogenesis by controlling the expression of the lipogenic enzymes mediated by the transcription factor, sterol regulatory element-binding protein-1c [25,29,37,38]. Moreover, the activation of brown adipose tissue and the induction of brown-like adipocytes in white adipose tissue (browning) seem to contribute to body fat reduction in resveratrol-treated rodents [34,36,39].

In humans, however, most of the research published until now shows a lack of effect on body adiposity and body weight. Trans-resveratrol supplementation at doses between 100 and $500 \mathrm{mg}$ for a 4-week to 6-month period did not affect fat mass or body weight in obese healthy individuals $[32,40,41]$. Despite this, adipocyte size was reduced, meaning that adipose tissue was modified by resveratrol intake, even if to a small degree [42]. Furthermore, two studies looking into the effect of resveratrol supplementation in patients with metabolic syndrome showed discrepant results; while Kjœr et al. [43] reported no effects on body composition with doses of $150 \mathrm{mg}$ and $1000 \mathrm{mg}$, Méndez del Villar et al. [44] showed a reduction in fat mass, waist circumference, body mass index, and body weight after receiving $500 \mathrm{mg}$ three times a day. However, patients with non-alcoholic fatty liver disease (NAFLD) or type 2 diabetes showed no changes regarding fat mass or body weight after resveratrol intake [45-48]. Moreover, other studies looking into the effect of resveratrol combined 
with other molecules, such as the intestinal lipase inhibitor orlistat [32] or epigallocatechin-3-gallate (EGCC) [49], did not show significant changes in fat mass.

\subsubsection{Resveratrol and Hepatic Fat Accumulation}

A lifestyle pattern including unbalanced diets and sedentary behavior promotes the accumulation of ectopic fat, particularly in the liver. As in metabolic syndrome, visceral adiposity and the pro-inflammatory state are also key in the development of NAFLD. In view of the inhibitory effects of resveratrol on fat accumulation, many studies have addressed its effect on hepatic fat and the management of NAFLD. Interestingly, hepatic triacylglycerol and cholesterol content is reduced by resveratrol supplementation in rodents fed a high-fat diet [26,50-55]. An increased number of mitochondria and fatty acid oxidation activity and a decreased lipogenic activity seem to be involved in normalizing hepatic steatosis in rodents $[50,51,55]$, in addition to the anti-oxidant and anti-inflammatory action of the polyphenol $[53,54]$. In humans, resveratrol supplementation was also shown to reduce intrahepatic lipid content in one study involving obese individuals [41], but not in another [40]. Furthermore, when considering patients with NAFLD, clinical trials are still insufficient to demonstrate a clear positive effect of resveratrol according to the conclusions of two meta-analyses, which show a lack of effect on NAFLD features [56,57]. Likewise, hepatic lipid deposition is unaffected in individuals with type 2 diabetes [58] or metabolic syndrome [43].

\subsection{Resveratrol and Glucose Intolerance and Insulin Resistance}

As it was demonstrated that resveratrol improves insulin sensitivity by activating AMPK [4], many later studies have evaluated the use of the polyphenol in the management of glucose control and in type 2 diabetes mellitus, the risk of which is increased under the persistence of glucose intolerance. Studies in cultured cells and animals have further contributed to the understanding of the mechanism of action of resveratrol on glycemic control and insulin resistance. Resveratrol activates the insulin-signaling components insulin receptor substrate- 1 and Akt $[59,60]$ and reduces the expression of adipokines that influence insulin sensitivity, including adiponectin [61], resistin, and retinol-binding protein 4 [33]. Resveratrol enhances insulin-stimulated glucose uptake in cultured cells [30] and, in vivo, reduces glycemia, insulinemia, and improves insulin resistance in diet-induced insulin-resistant mice $[4,60,62]$. Furthermore, the polyphenol protects from diabetic complications, such as diabetic nephropathy, diabetic retinopathy, and diabetes-induced hypertension [63-66].

When looking at the effects of resveratrol in a human setting, clinical trials have been conducted to elucidate its potential action on glucose homeostasis in individuals with different degrees of alteration in glucose homeostasis, from normoglycemia to type 2 diabetes. In non-diabetic individuals, four studies reported no changes in insulin sensitivity and insulin and glucose levels after resveratrol supplementation at doses between 75 and $2000 \mathrm{mg}$ [40,67-69]. However, in other studies, a decrease in circulating glucose, an improved homeostatic model assessment-insulin resistance (HOMA-IR) score and a suppression in postprandial glucagon response were observed after supplementation with a 150-mg resveratrol dose for 30 days in obese non-diabetic individuals [41,70]. However, in type 2 diabetic patients, it was ineffective in improving insulin sensitivity following the same supplementation protocol. It was speculated that the lack of effect could be due to the interaction found between metformin and dihydroresveratrol levels [58]. The intake of higher doses of resveratrol did not affect the circulating levels of glucose, insulin, glycosylated hemoglobin, and glucagon-like peptide- 1 in type 2 diabetic patients $[47,48]$, as well as glucose tolerance and insulin sensitivity in older glucose-intolerant adults [71]. A beneficial effect in glucose intolerant or type 2 diabetic patients is, on the other hand, described in other studies [72-75], even at low doses (10 mg) [73]. Furthermore, in individuals with NAFLD, no changes in insulin resistance were observed in several studies $[45,46,57]$, whereas glucose levels and insulin resistance were improved in one study [76]. Likewise, mixed outcomes are also reported in individuals with metabolic syndrome; while Méndez del Villar et al. [44] reported a decreased insulin response to glucose and total insulin secretion without affecting glucose 
levels, Kjœr et al. [43] reported no beneficial effects and actually found an increase in circulating fructosamine levels. Several meta-analyses have been carried out to shed light on the inconsistency of the above-mentioned results. In an early meta-analysis of 11 studies, Liu et al. concluded that there was no effect on glycemic measures in nondiabetic participants [77]. Among type 2 diabetic patients, Hausenblas et al. [78] identified a beneficial effect on hemoglobin A1c, but not on glucose, insulin, and HOMA-IR. More recently, a meta-analysis that included nine studies showed a beneficial effect on glucose and insulin levels and HOMA-IR, which was particularly more favorable for doses $\geq 100 \mathrm{mg} /$ day [6]. Despite the discrepant results, the sample size, and the duration of the trials, it concluded that resveratrol might be used for treating diabetes, alone or in combination with current anti-diabetic therapies $[66,79]$.

\subsection{Resveratrol and High Blood Pressure}

Excessive weight is linked to high blood pressure, which is a major risk factor for cardiovascular disease. Resveratrol supplementation reduces blood pressure in animal models of hypertension, including plexiglas clip- [80], angiotensin II- [81], or hypoxia-induced hypertensive rats, and in fructose-fed rats [82]. Several mechanisms are involved in the modulation of blood pressure by resveratrol, including AMPK phosphorylation, increased nitric oxide (NO) levels, SIRT1 activation, and decreased reactive oxygen species (ROS) production by regulating nicotinamide adenine dinucleotide phosphate oxidase, superoxide dismutase 2, and glutathione reductase [80-83]. In clinical trials, a reduction in blood pressure by resveratrol supplementation has been reported in individuals with obesity [41], NAFLD [84], or type 2 diabetes [72,85]; however, such an effect has not been found in other studies involving subjects with obesity [40,86], NAFLD [46], or metabolic syndrome [43]. Furthermore, several meta-analyses of randomized controlled trials show no significant effect of resveratrol supplementation on systolic and diastolic blood pressure [5,87], even though subgroup and meta-regression analyses indicate that resveratrol intake reduces systolic blood pressure and diastolic blood pressure at doses higher than $150-300 \mathrm{mg} /$ day $[5,88,89]$. According to these analyses, a beneficial effect of resveratrol supplementation on blood pressure is observed when the effect is analyzed among diabetic patients [89] or overweight and obese individuals [88]. Moreover, despite reporting no changes in blood pressure, resveratrol supplementation improves endothelial dysfunction in obese subjects [86], which is also seen in hypertensive patients [90] and individuals with mild hypertension [91].

\subsection{Hypertriglyceridemia}

Excessive fat intake and the persistence of increased adiposity can lead to dyslipidemia, which increases cardiovascular risk. Studies have been carried out evaluating the effect of resveratrol on circulating lipids, particularly triacylglycerides and cholesterol, offering interesting results. Resveratrol supplementation reduces triglyceridemia in diet-induced obese rodents $[25,26,54,55]$, which can be partly explained by the inhibition of hepatocyte fatty acid and triacylglycerol synthesis described in rat hepatocytes [92]. In humans, a reduction in triglyceridemia is observed when resveratrol is provided within a grape extract [93], mixed in a nutraceutical formula [94], or combined with other molecules, such as epigallocatechin-3-gallate (EGCC) [49] or orlistat [32]. When resveratrol is provided alone, it reduces plasma triglyceride levels in individuals with dyslipidemia [95] or obesity [58]. However, in other studies carried out in individuals with obesity [67], type 2 diabetes [74], NAFLD [46] or hypertriglyceridemia [68], resveratrol does not influence triglyceridemia, which is confirmed by Sahebkar's meta-analysis [87]. Furthermore, other studies actually report an increase in triglyceridemia, including Haghighatdosst's meta-analysis of 20 studies [3,48].

\subsection{Altered Cholesterolemia}

The effect of resveratrol on circulating levels of total, low-density lipoprotein (LDL), and HDL cholesterol has been evaluated. It is thought resveratrol may affect cholesterolemia by increasing 
the synthesis and efflux of bile acids, decreasing the synthesis of hepatic cholesterol, and increasing the efflux of cholesterol [96-98]. In this context, it has been shown that resveratrol supplementation reduces total cholesterol levels in diet-induced obese rodents $[25,26,54,55,97]$, whereas mixed results are reported in humans, showing either a lack of effect [67] toward the reduction [72,88,95], and even an increase in total cholesterol levels [43,48], as described for triglyceridemia. A lowering effect of resveratrol supplementation on plasma LDL and total cholesterol concentrations has been reported in studies in which the compound is given within a plant extract or when combined with a nutraceutical formula $[93,94,99]$, in which it was concluded that the presence of resveratrol is necessary to achieve this effect [99]. A recent meta-analysis of randomized clinical trials that used resveratrol as a mono food supplement concluded that the compound had no effect on the circulating levels of total, LDL, or HDL cholesterol [3]. In addition to its potential ability to influence cholesterol levels, resveratrol has been shown to inhibit LDL and HDL oxidation in vitro [98] and to reduce plasma oxidized LDL cholesterol levels [99].

\subsection{Inflammation and Oxidative Stress}

\subsubsection{Inflammation}

Studies have shown that resveratrol exerts an anti-inflammatory activity, and have demonstrated its capacity to inhibit the production of pro-inflammatory cytokines, as well as the activity of cyclooxygenases (COX)- 1 and -2 and inducible NO synthase. This anti-inflammatory effect is mainly mediated by the ability to inhibit the transcriptional activity of nuclear factor kappa beta (NF- $\mathrm{\beta} \beta$ ) and activator protein-1 [100], and can also be attributed to the modulatory effect of microRNAs expression with either an anti-inflammatory or a pro-inflammatory role [101]. Within this context, it has been revealed that resveratrol can decrease chronic low-grade inflammation, which is characterized by adipose tissue macrophage accumulation and abnormal cytokine production. For example, in murine adipocytes and human adipose tissue explants it decreases the secretion of monocyte chemoattractant protein-1 [102], tumor necrosis factor- $\alpha$ (TNF- $\alpha$ ), and interleukins (Il)-1 $\beta,-6$, and $-8[30,103,104]$, as well as the production of prostaglandin E2 [105], and the expression of vascular endothelial growth factor [106]. These effects are observed in cells treated with TNF- $\alpha$ or Il-1 $\beta$, exposed to hypoxic conditions, or treated with the microbial product lipopolysaccharide (LPS) [59,107]. In vivo, resveratrol intake reverses obesity-associated inflammation in genetically-induced obese rats [108] and diet-induced obese rodents and monkeys [25,54,55,109-112]. Furthermore, several human studies have reported that resveratrol can even have an acute anti-inflammatory effect in healthy subjects. For example, the intake of a single grape extract reduces plasma IL- $1 \beta$ levels induced by a high-fat and high-carbohydrate meal and, interestingly, plasma endotoxin levels [113]. In type 2 diabetic and hypertensive patients, long-term grape extract supplementation reduces serum Il-6 and alkaline phosphatase levels and alters the expression of pro-inflammatory genes and microRNAs in peripheral blood mononuclear cells [114]. However, in a study involving type 2 diabetic patients, $800 \mathrm{mg}$ /day resveratrol supplementation did not change plasma levels of inflammatory cytokines [115]. Meta-analyses of randomized controlled trials indicate that resveratrol treatment reduces the levels of C-reactive protein and that of TNF- $\alpha$ among obese subjects, confirming the anti-inflammatory action of resveratrol [116]. Interestingly, the pro-inflammatory status which occurs in diabetic complications, such as diabetic neuropathy and nephropathy, seems to also be inhibited by resveratrol $[64,117]$.

\subsubsection{Oxidative Stress}

Resveratrol exerts an anti-oxidant action, which underlies the beneficial effect of this polyphenol on several metabolic disturbances, such as glucose intolerance, insulin resistance, and hepatic fat accumulation. The mechanisms of action of its anti-oxidant effects include direct mechanisms, such as neutralizing ROS and reactive nitrogen species, and indirect mechanisms such as the ability to increase the transcriptional activity of nuclear factor-E(2)-related factor-2 (Nrf2) and forkhead box 
O [118]. Experiments on cell cultures designed to study the effect of resveratrol on metabolic syndrome alterations, particularly by exposing cells to a high glucose concentration or to pro-inflammatory cytokines, show a reduction in ROS levels in many cell types, including in vascular endothelial cells [119,120], adipocytes [104], monocytes [121], and cardiomyocytes [122]. In obese and/or diabetic rodents, a reduction in oxidative stress accompanies the improvement of inflammation $[55,110,112]$, hyperglycemia and insulin resistance [62,112], diabetic nephropathy [63], fat mass accumulation [112], hepatic steatosis [52,53,55,123], hypertriglyceridemia [55], hypercholesterolemia [55], endothelial function [124,125], ventricular diastolic relaxation [126], and hypertension [123]. In humans, the intake of resveratrol reduces oxidative stress in both healthy individuals and patients with metabolic diseases that are characterized by a high oxidative stress degree. The intake of a resveratrol supplement or resveratrol-containing extract increases the total antioxidant capacity and reduces oxidative stress in healthy individuals $[93,94,127]$, as well as oxidative stress generated by the intake of a meal rich in fat [113]. In type 2 diabetic patients, resveratrol supplementation reduces markers of oxidative stress, which are accompanied by an improvement of insulin sensitivity, blood pressure, and cardiovascular function $[73,85]$. The improvement in insulin sensitivity and diabetic complications caused by resveratrol is explained by its ability to reduce oxidative stress $[64,65,73]$. Since resveratrol is a relatively unstable molecule, strategies aimed at increasing its stability and thus enhancing its inhibitory action on oxidative stress have been developed. In this context, an enhanced reduction in oxidative stress in obese individuals has been achieved by the intake of a more stable resveratrol derivative [128].

\section{Role of Resveratrol Metabolites in Metabolic Syndrome}

Most of the studies dealing with the potential beneficial effects of resveratrol on metabolic syndrome use trans-resveratrol. However, in vivo effects cannot be solely attributed to this molecule, as it is likely that resveratrol metabolites are also involved. As detailed above, upon intake, several resveratrol metabolites can be produced in the body, including piceid, glucuronide, and sulfate resveratrol conjugates, dihydroresveratrol and other derivatives produced by gut microbiota, and piceatannol, among others. One of the most studied resveratrol metabolites is piceid, which shows a higher bioavailability than resveratrol. As described for resveratrol, piceid shows anti-oxidant and anti-inflammatory activities and shares with resveratrol many of the described molecular targets, including SIRT1, NF- $\mathrm{\beta} \beta$, and NRF2. Interestingly, its anti-oxidant activity is higher than that of resveratrol [129]. In vivo, piceid treatment reduces insulin resistance, steatosis, and dyslipidemia [130-132]. Regarding resveratrol conjugates, there are little data on their potential metabolic effects. Resveratrol glucuronides and sulfates inhibit triacylglycerol accumulation in differentiating adipocytes and adipokine expression in mature adipocytes [133,134]. Additionally, resveratrol glucuronides seem to have a greater potential to lowering the effect of cholesterol [96] compared to resveratrol, whereas resveratrol sulfates inhibit NO production and exert a differentiated effect when compared to glucuronides on free radical scavenging and COX activity, NF- $\kappa \beta$ induction, and pro-inflammatory cytokine expression inhibition $[135,136]$. It would be interesting to elucidate whether the resveratrol metabolites produced by gut bacteria are able to trigger beneficial effects, particularly bearing in mind the high concentrations of dihydroresveratrol and its derivatives detected in plasma and tissues $[16,23]$. Only limited data exist regarding the effects of dihydroresveratrol, 3,4'-dihydroxy-trans-stilbene, and lunularin in parameters related to metabolic syndrome. Dihydroresveratrol exhibits significant antioxidant activity [137], reduces fatty acid-binding protein-4 expression, involved in fatty acid uptake in human macrophages treated with oxidized LDL [138] and stimulates fatty acid oxidation in human fibroblasts [139]. Lunularin reduces the expression of pro-inflammatory mediators in endothelial cells in response to LPS [140], and 3,4'-dihydroxy-trans-stilbene activates AMPK, induces glucose uptake in C2C12 myotubes, and reduces PPARg and resistin expression in 3T3-L1 adipocytes, showing a larger effect than resveratrol [141]. Collectively, these results suggest that gut bacteria-derived resveratrol metabolites could be involved in the effect of resveratrol supplementation on metabolic syndrome alterations, 
and consequently, gut bacteria amount and composition may be determinant. A resveratrol-related stilbenoid with reported effects against metabolic syndrome alterations is piceatannol, which inhibits fatty acid-induced inflammation and oxidative stress and reduces hyperlipidemia, hyperglycemia, and insulin resistance [19,100,142-144]. Research has thus focused on this stilbenoid due to its higher stability and absorption compared to resveratrol [145], which is associated with a higher anti-inflammatory activity versus resveratrol [146]. Moreover, differential effects between these stilbene derivatives have been shown regarding their anti-lipolytic activity, being stronger for piceatannol, which was linked to its inhibitory action on lipotoxicity [143]. Overall, it seems that resveratrol metabolites could be involved in some of the beneficial effects attributed to resveratrol with regards to the metabolic syndrome alterations. The fact that the gut microbiota plays an important role in the conversion and/or production of some of these resveratrol-related metabolites has led to the idea that it could actually be modulating such described effects.

\section{The Role of Gut Microbiota in Health and Disease}

The gut microbiota, including its role in health and disease, is currently one of the topics of highest interest in biomedical research, due to its potential key role in the aetiology and development of many diseases $[147,148]$. In the last decade, it has been associated with conditions such as obesity, diabetes, cardiovascular disease, and cancer, which are among the leading causes of mortality and morbidity worldwide [149-153]. More recently, the hypothesis that the gut microbiota is one of the key modulators that influence disease risk due to its close links to metabolism and the immune system has been posed [154]. It was even coined as "the forgotten organ" initially [155], due to the vast amount of processes it is involved in, including the processing of non-digestible polysaccharides from the diet into short-chain fatty acids (SCFA) [156], synthesis of vitamins, and regulation of energy balance and immune functions [147,157]. The term "gut microbiota" refers to the bacteria, archaea, and eukarya found in the gastrointestinal tract [158]. It is widely thought that the number of microorganisms greatly outnumber human cells (with a suggested ratio of 1:10) [159], and 100 times the amount of genomic content ("gut microbiome") [158], which inevitably leads to the assumption that they carry out a major role in the body; interestingly, this calculation was recently challenged and the idea that the ratio may be closer to 1:1 was put forward [160], without underestimating their impact on human health. This new focus on the role of gut microbiota on health and disease has led to large studies worldwide, including the Human Microbiome Project [161], which was essentially an extension of the Human Genome Project, and the MyNewGut project, which is currently ongoing and focuses on the role of the microbiome in the development of diet and brain-related disorders, among others. The ultimate goal of this new "gut microbiota era" is to understand what bacterial composition defines a healthy gut, and how this knowledge can be translated into efficient and targeted therapies for diseases in which it seems to be playing a main role.

Initially, it was thought that humans could be divided into three main enterotypes based on the make-up of their gut microbiota composition, focusing on one of three dominating genera: Bacteroides, Prevotella, and Ruminococcus [162]; since then it has been shown that gut bacteria are easily modified by many factors, including delivery method, diet, lifestyle, medication use, and infections [148,163-165], making an individual's enterotype variable throughout their lifespan and hence the use of bacterial clusters as biomarkers for disease not as effective as previously thought [166]. Although it is still being debated what constitutes a "healthy" gut microbiota composition, it has been widely established that dysbiosis, which refers to a disturbance in the amount and/or composition of an individual's "normal" gut microbiota, is strongly associated to many common diseases [150,152,154,163]. People presenting certain conditions, such as obesity and metabolic syndrome particularly, consistently present a lower bacterial diversity and composition compared to their healthy counterparts [153,163,167-171]. Furthermore, it was recently hypothesized that since a more diverse microbiota translates into carrying more genes and is involved in more metabolic pathways, it is better prepared to adapt to changes in diet and thus the host could respond better to dietary treatment [172]. 


\subsection{The Impact of Gut Microbiota on Energy Metabolism}

As previously discussed, the potential modulation of energy homeostasis by the gut microbiota has been of great interest, with studies indicating significant differences between the gut microbiota of obese versus lean subjects. Many animal studies are offering potential mechanistic views on how the gut microbiota operates, and although this proves to be more challenging in a human setting [173], evidence continues to point to the "forgotten organ" as one of the key players.

Over a decade ago, the first data emerged showing that germ-free mice weighed significantly less and had a lower amount of body fat [174-176]. Since then, numerous studies have shown that the gut microbiota composition in obesity is different compared to lean subjects, characterized by increased levels of Firmicutes and less Bacteroidetes [177,178], increased capacity in energy harvesting from dietary polysaccharides $[175,179]$, and is associated with increased adiposity and insulin resistance $[180,181]$ and lower levels of short-chain fatty acids in the caecum [173].

Furthermore, more and more evidence points towards the significant role of systemic and adipose tissue inflammation in the development of obesity, diabetes, and metabolic syndrome, thus many studies soon began to investigate whether gut microbiota could be contributing to it [182-185]. It has been shown that LPS, found on the outer membrane of Gram-negative bacteria, triggers inflammatory pathways by binding the CD14/Toll-like receptor- 4 complex and that chronic high levels in plasma lead to insulin resistance and diabetes [185-187]. Hence, it is hypothesized that certain factors (such as diet) can promote Gram-negative bacteria in the gut, promoting leakage of LPS through the gut epithelium and thus leading to an increase in plasma LPS levels, inducing insulin resistance and what is known as metabolic endotoxaemia $[172,188]$.

Thus, it seems that the gut microbiota has a big impact at both the peripheral and the central level with regard to overall energy regulation, and hence it is being considered as a potential therapeutic strategy for subjects who present obesity, diabetes and/or metabolic syndrome. One of the key ways to manipulate gut microbiota is through the diet, as discussed in the next section, with a focus on the influence of natural polyphenols.

\subsection{Diet as a Key Modulator of the Gut Microbiota}

Data so far point to the gut microbiota and its metabolic products as a key player in obesity and metabolic syndrome $[149,150,152]$, hence the next step at present is to determine plausible ways in which to manipulate bacterial composition in order to impact host physiology in a beneficial manner. Evidence suggests that gut microbiota may be the link between diet and obesity development, due to its capacity for changing microbial composition and activity in the gut, as seen in both mice and humans $[149,150,152]$. Therefore, it is essential to consider diet as an important factor when designing new therapies and prevention strategies regarding obesity [189-191].

Dietary habits on the whole have a significant role in shaping the gut microbiota-this is evidenced by the fact that individuals of different countries have distinct bacterial populations [192]. One of the first studies to publish this was carried out by De Filippo et al., which showed that children in a rural African village had low levels of Firmicutes and high levels of Bacteroidetes in fecal samples compared to Italian children, who presented high levels of Enterobacteriaceae [193].

Furthermore, even though gut microbiota is relatively stable throughout adulthood in humans [194], studies have shown that it can be rapidly modified by diet [195], with composition changes seen in as little as a few days of dietary intervention [174]. However, it seems this can be rapidly reversed, hence it has been suggested that a long-term (dietary) intervention may be needed in order to observe a significant shift in the enterotype of an individual [196].

Research has mainly focused on the effect of certain dietary patterns, such as high-fat and/or "Western" diets, which lead to decreased bacterial diversity, high numbers of Firmicutes and Proteobacteria, and low Bifidobacteria levels, which in turn are associated to a wide array of conditions, particularly obesity [196-198]. Other dietary interventions, such as the use of fructans, high-fiber, specific nutrients or prebiotics have been shown to promote bacterial diversity and increase 
Bifidobacteria in the gut, and thus having an overall beneficial effect on the host, such as decreasing low-grade inflammation $[167,195,198,199]$.

Within the study of specific macro and micronutrients, we find an increased interest in the effects of molecules such as polyphenols, which have the ability to cause a significant shift in gut microbiota [12]. Here we will focus particularly on the effect of resveratrol has on the gut microbiota and how this knowledge could be used in the context of obesity and the metabolic syndrome.

\subsection{Resveratrol and Gut Microbiota}

Owing to the low bioavailability of resveratrol, it has been postulated that one of its mechanisms of action is through its interaction with the gut [200]. Recent studies have shown that resveratrol induces changes in the gut microbiota, which could lead to lower body weight and body fat, together with improved glucose homeostasis and obesity-related parameters. It seems this could be either by directly modulating bacterial populations to promote a composition associated with a healthy phenotype, or by the action of its by-products, which could be having an impact on genes and pathways involved in energy regulation. A summary of the studies discussed in this section can be found in Table 1 .

Table 1. Review of studies analyzing the effect of resveratrol on gut microbiota composition.

\begin{tabular}{|c|c|c|c|c|c|}
\hline Species & $\begin{array}{c}\text { Resveratrol } \\
\text { Dose }\end{array}$ & Duration & $\begin{array}{c}\text { Modulation of Gut } \\
\text { Microbiota }\end{array}$ & \multicolumn{2}{|c|}{ Effects on Metabolic Syndrome Alterations } \\
\hline $\mathrm{C} 57 \mathrm{Bl} / 6 \mathrm{~N}$ mice & $\begin{array}{l}0.4 \% \\
\text { resveratrol } \\
(+\mathrm{FMT})\end{array}$ & 2-8 weeks & $\begin{array}{c}\uparrow \text { Bacteroides and } \\
\text { Parabacteroides } \\
\downarrow \text { Turicibacteraceae, Moryella, } \\
\text { Lachnospiraceae and } \\
\text { Akkermansia }\end{array}$ & $\begin{array}{l}\text { FMT from resveratrol-fed } \\
\text { mice improved glucose } \\
\text { homeostasis and lowered } \\
\text { blood pressure. }\end{array}$ & {$[201,202]$} \\
\hline $\begin{array}{l}\mathrm{C} 57 \mathrm{Bl} / 6 \mathrm{~J} \text { and } \\
\mathrm{ApoE}^{-/-} \text {mice }\end{array}$ & $\begin{array}{c}0.4 \% \\
\text { resveratrol }\end{array}$ & 1 or 2 months & $\begin{array}{l}\uparrow \text { Lactobacillus and } \\
\text { Bifidobacterium }\end{array}$ & $\begin{array}{l}\text { Inhibition of TMAO synthesis } \\
\text { and reduced atherosclerosis. }\end{array}$ & [203] \\
\hline $\mathrm{C} 57 \mathrm{Bl} / 6 \mathrm{~N}$ mice & $\begin{array}{c}450 \\
\mathrm{mg} / \mathrm{kg} / \text { day }\end{array}$ & 2 weeks & $\begin{array}{c}\downarrow \text { Bacteriodetes-to-Firmicutes } \\
\text { ratio } \\
\uparrow \text { Parabacteroides, Bilophila } \\
\text { and Akkermansia } \\
\downarrow \text { Lachnospiraceae }\end{array}$ & $\begin{array}{c}\text { Increased skeletal muscle } \\
\text { insulin sensitivity, glucose } \\
\text { utilization and metabolic rate. }\end{array}$ & [204] \\
\hline C57Bl/6J mice & $200 \mathrm{mg} / \mathrm{kg} /$ day & 8 weeks & $\begin{array}{c}\downarrow \text { Lactococcus, Clostridium XI, } \\
\text { Oscillibacter \& } \\
\text { Hydrogenoanaerobacterium }\end{array}$ & $\begin{array}{l}\text { Reduced fat deposition and } \\
\text { body weight gain. }\end{array}$ & [205] \\
\hline C57Bl/6 mice & $\begin{array}{c}0.1 \% \\
\text { resveratrol, } \\
0.1 \% \\
\text { piceatannol or } \\
0.25 \% \\
\text { piceatannol }\end{array}$ & 18 weeks & $\begin{array}{c}\text { Piceatannol: } \\
\uparrow \text { Firmicutes, Clostridiales, } \\
\text { Shpingobacteriales, Blautia, } P \text {. } \\
\text { kwangyangensis \& Lactobacillus } \\
\downarrow \text { Bacteroidetes }\end{array}$ & $\begin{array}{c}\text { Piceatannol: } \\
\text { Reduced body weight, } \\
\text { perigonadal adipose tissue, } \\
\text { adipocyte size, plasma glucose } \\
\text { and cholesterol } \\
\text { Resveratrol: } \\
\text { Reduced perigonadal adipose } \\
\text { tissue, adipocyte size }\end{array}$ & [206] \\
\hline Kunming mice & $200 \mathrm{mg} / \mathrm{kg} /$ day & 12 weeks & $\begin{array}{c}\uparrow \text { Bacteroidetes, Lactobacillus \& } \\
\text { Bifidobacterium } \\
\downarrow \text { Firmicutes and Enterococcus } \\
\text { faecalis }\end{array}$ & $\begin{array}{l}\text { Decreased body and visceral } \\
\text { adipose weight. } \\
\text { Lower plasma glucose and } \\
\text { lipid levels. }\end{array}$ & [207] \\
\hline $\begin{array}{l}\text { C57Bl/6J and } \\
\text { Glp1r mice }\end{array}$ & $60 \mathrm{mg} / \mathrm{kg} /$ day & 5 weeks & $\begin{array}{c}\text { Restored bacterial } \\
\text { composition of animals fed a } \\
\text { high-fat diet. } \\
\downarrow \text { Parabacteroides jonsonii DMS } \\
18315 \text { (a), Alistipes putredinis } \\
\text { DMS } 17216 \text { (b) and Bacteroides } \\
\text { vulgatus ATCC } 8482\end{array}$ & $\begin{array}{l}\text { Reduced glucose intolerance } \\
\text { in diabetic mice without } \\
\text { affecting fasting glycemia. }\end{array}$ & [208] \\
\hline
\end{tabular}


Table 1. Cont.

\begin{tabular}{|c|c|c|c|c|c|}
\hline Species & $\begin{array}{l}\text { Resveratrol } \\
\text { Dose }\end{array}$ & Duration & $\begin{array}{l}\text { Modulation of Gut } \\
\text { Microbiota }\end{array}$ & \multicolumn{2}{|c|}{ Effects on Metabolic Syndrome Alterations } \\
\hline Wistar rats & $\begin{array}{c}\text { Quercetin }(30 \\
\mathrm{mg} / \mathrm{kg} / \text { day }) \\
\text { and resveratrol } \\
(15 \\
\mathrm{mg} / \mathrm{kg} / \text { day })\end{array}$ & 10 weeks & $\begin{array}{c}\uparrow \text { Bacteroidales S24-7 group, } \\
\text { Christensenellaceae, } \\
\text { Akkermansia muciniphila, } \\
\text { Ruminococcaceae, } \\
\text { Ruminococcaceae UCG-014 \& } \\
\text { Ruminococcaceae UCG-005 } \\
\downarrow \text { Firmicutes \& } \\
\text { Firmicutes-to-Bacteroidetes } \\
\text { ratio }\end{array}$ & $\begin{array}{l}\text { Lower body weight gain and } \\
\text { adipose tissue weight. }\end{array}$ & [209] \\
\hline $\begin{array}{l}\text { Zucker rat } \\
(f a / f a)\end{array}$ & $\begin{array}{l}\text { Piceatannol (15 } \\
\text { and } 45 \\
\mathrm{mg} / \mathrm{kg} / \text { day })\end{array}$ & 6 weeks & $\downarrow$ Clostridium hathewayi & $\begin{array}{l}\text { No impact on body weight } \\
\text { and body fat, glucose, and } \\
\text { lipid metabolic parameters. }\end{array}$ & [210] \\
\hline Wistar rats & $\begin{array}{c}\text { Trans-resveratrol } \\
\text { (15 } \\
\mathrm{mg} / \mathrm{kg} / \text { day) or } \\
\text { trans-resveratrol } \\
+ \text { quercetin }(30 \\
\mathrm{mg} / \mathrm{kg} / \text { day })\end{array}$ & 6 weeks & $\begin{array}{l}\text { Trans-resveratrol \& quercetin: } \\
\downarrow \begin{array}{c}\downarrow \text { Firmicutes-to-Bacteroidetes } \\
\text { ratio }\end{array} \\
\downarrow \text { Erysipelotrichaceae, Bacillus, } \\
\text { Eubacterium cylindroides }\end{array}$ & $\begin{array}{l}\text { Improved HOMA-IR and } \\
\text { insulin sensitivity. }\end{array}$ & [211] \\
\hline $\begin{array}{c}\text { Sprague } \\
\text { Dawley rats }\end{array}$ & $\begin{array}{l}50 \mathrm{mg} / \mathrm{L} \text { of } \\
\text { resveratrol } \\
50 \mathrm{mg} / \mathrm{L}\end{array}$ & 3 months & $\begin{array}{c}\uparrow \text { Firmicutes-to-Proteobacteria } \\
\text { ratio }\end{array}$ & $\begin{array}{l}\text { Restored systolic and diastolic } \\
\text { blood pressure. }\end{array}$ & [212] \\
\hline Humans & $\begin{array}{c}\text { EGCG }(282 \\
\mathrm{mg} / \text { day })+ \\
\text { resveratrol }(80 \\
\mathrm{mg} / \text { day) }\end{array}$ & 12 weeks & $\begin{array}{c}\text { Men: } \\
\downarrow \text { Bacteroidetes }\end{array}$ & $\begin{array}{l}\text { Increased fat oxidation and } \\
\text { skeletal muscle mitochondrial } \\
\text { oxidative capacity. }\end{array}$ & [213] \\
\hline
\end{tabular}

\subsubsection{Effects of Resveratrol on Body Weight and Fat Metabolism}

As previously discussed in this review, resveratrol could have a beneficial effect on body weight and body fat regulation based on evidence obtained in experimental animals, and studies are starting to point towards a potential implication of the gut microbiota as reviewed in Table 1. One study showed that C57Bl/6J mice on a high-fat diet and receiving $200 \mathrm{mg} / \mathrm{kg} /$ day of resveratrol supplementation through oral gavage five times a week (for a total of eight weeks) presented reduced fat deposition and body weight gain compared to controls receiving a high-fat diet alone [205]. In order to understand the potential mechanism through which resveratrol acts, the authors show that resveratrol activated the mammalian target of the rapamycin (mTOR) complex 2 (mTORC2) signalling pathway and inhibited mTORC1, a key player in energy regulation, suggesting that this suppresses the presence of obesity-associated gut microbiota, including Lactococcus, Clostridium XI, Oscillibacter, and Hydrogenoanaerobacterium.

In tune with these results, Kunming mice on a high-fat diet supplemented with the same amount of resveratrol $(200 \mathrm{mg} / \mathrm{kg} /$ day) for 12 weeks also showed decreased body fat and weight by the end of the experiment [207]. These parameters were correlated with changes in gut microbiota, since resveratrol significantly increased Lactobacillus and Bifidobacterium (negatively correlated with body weight), and decreased Enterococcus faecalis (positively correlated with body weight). Furthermore, they showed a higher abundance of Bacteroidetes and a lower amount of Firmicutes bacteria (a ratio which was negatively correlated with body weight). Although the authors suggest that resveratrol could be having a prebiotic effect on bacteria, and that this could be having a positive effect on body weight and fat mass, further studies are needed to identify the potential mechanisms through which resveratrol acts.

Other studies have looked at the effect of resveratrol supplementation together with other compounds of interest. For example, one group administered a combination of quercetin $(30 \mathrm{mg} / \mathrm{kg}$ body weight) and resveratrol ( $15 \mathrm{mg} / \mathrm{kg}$ body weight) by oral gavage per day to Wistar rats on a high-fat diet for 10 weeks [209]. By the end of the experiment, animals receiving supplementation 
presented lower body weight gain and adipose tissue weight compared to animals on a high-fat diet alone. Interestingly, they also had decreased Firmicutes and a lower Firmicutes to Bacteroidetes ratio, as well as increased levels of Bacteroidales S24-7 group, Christensenellaceae, Akkermansia muciniphila, Ruminococcaceae, Ruminococcaceae UCG-014, and Ruminococcaceae UCG-005, which have all been associated with reducing high-fat-diet-induced obesity.

In line with these results, it seems resveratrol could be a promising compound for use in promoting a healthy gut microbiota, which is known to have a wide array of beneficial effects. However, to the best of our knowledge, very few studies have been carried out which investigate the effects of resveratrol supplementation on gut microbiota in humans and the results obtained were slightly milder than those observed in animals. A recent study gave both males and females a combination of epigallocatechin-3-gallate (282 mg/day) and resveratrol (80 mg/day) supplements for 12 weeks; by the end of the experiment, they observed only slight differences in the gut microbiota composition of men only, with a minor reduction in Bacteroidetes and Faecalibacterium prausnitzii [213]. However, an increase in fat oxidation and skeletal muscle mitochondrial oxidative capacity was observed associated with supplementation and, interestingly, the Bacteroidetes level was correlated with fat oxidation in men.

\subsubsection{Resveratrol Potentially Improves Glucose Homeostasis through the Gut Microbiota}

Recent studies have focused on whether the beneficial effect of resveratrol supplementation on glucose homeostasis may be mediated, at least in part, by alterations in the gut microbiota. Two recent studies carried out by the same group using a fecal microbiota transplant (FMT) show that obese mice receiving a resveratrol (0.4\%)-fed mice-FMT present less Proteobacteria [201,202]; considering the association of Proteobacteria with inflammation, the authors postulated that the reduction observed could be indicative of the benefits seen in treated animals. Furthermore, they also reported decreased inflammation in the colon of FMT-recipients and suggested that bacterial metabolites or by-products of the polyphenol may be responsible for these benefits. In contrast, the authors reported decreased levels of Akkermansia muciniphila, a species that has been associated to improved body weight and glucose management. An interesting observation however was that resveratrol-FMT is actually more efficient than oral supplementation per se for the regulation of glucose homeostasis once obesity and insulin resistance are already present [201,202]. Decreased intestinal inflammation linked to resveratrol supplementation and improved glucose homeostasis has also been reported [208], in which C57Bl/6J and glucagon-like peptide-1 (GLP-1) receptor knock-out (Glp1r ${ }^{-/}$) mice on a high-fat diet supplemented with $60 \mathrm{mg} / \mathrm{kg} /$ day of resveratrol for five weeks showed an increase in glucose-induced glucagon-like peptide-1 (GLP-1) and insulin secretion. This was accompanied by changes in gut microbiota composition, which suggest to be linked to the decreased intestinal inflammation in these animals. It is hypothesised that animals on a high-fat diet have increased inflammation, which leads to decreased glucose-induced insulin secretion and ultimately insulin resistance [185]. Thus, it seems that resveratrol may potentially mitigate intestinal inflammation caused by high-fat feeding via gut microbiota modulation, which could in turn increase incretin actions such as insulin and GLP-1 secretion and ameliorate glycemic control. Hence, based on the in vivo demonstration of the influence of resveratrol on the enteroendocrine axis in mice [208], a novel therapeutic action of this polyphenol should be considered.

In another study, C57Bl/6N mice with induced heart failure were administered a high dose of resveratrol (450 mg/kg/day) together with a high-fat diet for two weeks and reported a decreased Bacteroidetes-to-Firmicutes ratio in the gut microbiota and an increase in the genus Akkermansia [204]. This latter one, as previously mentioned, has been linked to improved glucose homeostasis in insulin-resistant and obese animal models, and is in contrast with what was observed in the above-discussed studies. This was accompanied by a higher abundance of the genera Parabacteroides and Bilophila, and a decrease in the Lachnospiraceae family, changes which are associated to 
an increased metagenomics capacity for carbohydrate metabolism, indicating a potential mechanism by which resveratrol improves insulin signaling and glucose homeostasis.

Rats under a high-fat, high-sucrose diet were supplemented with either trans-resveratrol $(15 \mathrm{mg} / \mathrm{kg}$ body weight/day) or with a combination of trans-resveratrol and quercetin $(30 \mathrm{mg} / \mathrm{kg} / \mathrm{day})$ for six weeks [211]. Besides a reduced weight gain, animals receiving the polyphenols exhibited lower serum insulin levels and improved insulin sensitivity. Treatments did not alter bacteria at the phylum level, however trans-resveratrol did reduce significantly the Graciibacteraceae family, the Parabacteroides genus, and the species Clostridium aldenense, Clostridium hathewayi, Clostridium sp. C9, Clostridium sp. MLG661, Gracilibacter thermotolerans and Parabacteroides distasonis, as well as increasing significantly the relative abundance of Clostridium sp. XB90 versus animals on a high-fat, high-sucrose diet alone. Even though these changes were accompanied by a decrease in HOMA-IR, the authors could not conclude a direct association between the changes observed in gut microbiota and the beneficial effects seen in insulin resistance.

\subsubsection{Effects on Cardiovascular Health}

Cardiovascular health is closely related to metabolic syndrome, which, as described above, is characterized by abdominal fat, high glucose, and triglyceride levels, low high-density lipoprotein cholesterol levels, and hypertension [214]. Thus, determining therapies to promote a healthy cardiovascular system will inevitably lead to an improvement of the metabolic syndrome outcome. Within this context, one group showed a protective effect of resveratrol on atherosclerosis by supplementing C57BL/6 and $\mathrm{ApoE}^{-/-}$mice with $0.4 \%$ resveratrol. Supplementation increased levels of the genera Lactobacillus and Bifidobacterium, and decreased gut microbial trimethylamine production through changes in the gut microbiota, hence leading to inhibited trimethylamine-n-oxide synthesis and reduced atherosclerosis [203]. Interestingly, another study investigated the effect of supplementing Sprague Dawley rats with $50 \mathrm{mg} / \mathrm{L}$ of resveratrol in their drinking water during pregnancy and lactation whilst on a high-fructose diet [212]. They observed that the offspring from animals receiving resveratrol presented a restored systolic and diastolic blood pressure versus animals not receiving supplementation, which was elevated compared to control rats. This was accompanied by changes in gut microbiota since animals receiving a high-fructose diet presented a decreased Firmicutes-to-Proteobacteria ratio, which was normalized by resveratrol intake. Furthermore, it seems that supplementation increased the relative abundance of Lactobacillus and Bifidobacterium species, which was in accordance with that observed by Chen et al. [203], thus counteracting the impact of the high-fructose diet [212]. However, further studies are needed to determine whether such changes can be directly attributed to the beneficial impact of resveratrol on hypertension.

\subsubsection{Resveratrol Analogues and Gut Microbiota}

Due to the reported low bioavailability of resveratrol, a few studies have been carried out to explore the potential effects of analogs such as piceatannol [215], a polyphenol that presents better bioavailability. However, the studies published so far present differing results. On the one hand, one group showed that the administration of piceatannol (15 or $45 \mathrm{mg} / \mathrm{kg} /$ day for six weeks) to Zucker (fa/fa) rats has little effect on gut microbiota, as well as no major impact on body weight, body fat, and glucose and lipid metabolic parameters, other than a decrease in circulating non-esterified fatty acids and in fecal Clostridium hathewayi, belonging to the butyrate-produce cluster Clostridium XIVa [210]. On the other hand, another study showed that $0.25 \%$ piceatannol supplementation under a high-fat diet reduced the body weight of $C 57 \mathrm{Bl} / 6 \mathrm{~N}$ mice, and that both $0.1 \%$ resveratrol and $0.1 \%$ and $0.25 \%$ piceatannol were able to partially prevent the increase of body fat content and adipocyte size compared to a high-fat diet alone [206]. This was accompanied by significant changes in gut microbiota, where animals supplemented with piceatannol particularly recovered from the alterations caused by a high-fat diet, which intriguingly consisted of a decreased Firmicutes abundance and increased Bacteroidetes [206]. The differences in the results between these two studies could be due to a variety 
of reasons, such as different concentrations and length of supplementation, together with different metagenomic workflow. Furthermore, the results of the latter study, reporting a piceatannol-induced increase in Firmicutes versus animals on a high-fat diet deserves further confirmation, since it has been well documented that this dietary intervention, revealing an obese phenotype, is generally associated to dysbiosis and lower bacterial diversity [197]. Otherwise, the rapid action of piceatannol, which results in lowering blood glucose $1 \mathrm{~h}$ after acute oral administration in $d b / d b$ mice $(50 \mathrm{mg} / \mathrm{kg}$ body weight), indicates that not all the beneficial effects of stilbenoids are mediated by a modulatory action effect on gut microbiota [144]. Together with the interactions between stilbenoids and bacteria, changes at the intestinal level and even in other targets, warrant further study regarding the potential of polyphenols for the chronic treatment of metabolic syndrome. However, such future investigations should not consider these metabolites as inactive; as mentioned above and as illustrated by the case of urolithin A, a major ellagitannin metabolite, they are endowed with noticeable health benefits [216].

\section{Future Directions}

When reflecting on the impact a certain compound has on health, in this case, resveratrol, and whether its effects may be mediated by gut microbiota, many questions appear: Is gut microbiota at the base of energy regulation? Could resveratrol be having a significant impact on it, making it relevant to consider it a prebiotic in the future? Thus, there are still many issues to consider and investigate in the near future.

As recently reviewed [217], the modulation of gut microbiota is being considered as a key method to treat obesity. However, it is seen that the efficiency of this strategy is inconsistent due to inherent differences in gut microbiota among individuals. Furthermore, it is yet to be determined what an "ideal" gut microbiota composition is and how to effectively manipulate it.

Although the results so far are promising, further studies are warranted in both animals and humans. It seems that resveratrol does have an effect on gut microbiota that was initially unsuspected when, more than a decade ago, the stilbenoid was found to modulate energy balance. Now, resveratrol is considered as a potential prebiotic candidate to promote changes in bacterial composition associated with a healthy phenotype. However, whether this interaction is involved in several of the beneficial health effects attributed to this polyphenol is yet to be elucidated. At present, and to the best of our knowledge, most studies are still observational, and nearly all in animal models, presenting interesting correlations but few mechanistic clues as to how the resveratrol-gut microbiota-metabolism axis could be functioning. As discussed above, it seems that in the past 10 years most studies have shown associations between gut microbiota and health and disease, but they have failed to prove a direct causal relationship [154]. One of the potential mechanisms put forward by Nohr et al. [218] could be that resveratrol reverses or inhibits the effects of Gram-negative bacteria-derived LPS in the gut, thereby preventing an alteration of the intestinal epithelium permeability, and consequently decreasing endotoxemia of intestinal origin, low-grade inflammation, and obesity. However, more studies are needed in order to confirm this interesting hypothesis. Another future route of study could be to analyze the potential effects of resveratrol on SCFA in the gut since recent studies seem to be pointing to the by-products of resveratrol as the key actors, including SCFA, already known to play a regulatory role in energy homeostasis.

At this stage, and considering the observations made in different models, we hypothesize two putative mechanisms of action of resveratrol on the interactions between bacteria and intestinal mucosa.

First, resveratrol may influence the turnover of SCFA and various intraluminal lipids by modulating both bacterial production and handling in the intestine. Indeed, resveratrol has been reported to exert an important anti-lipogenic effect on an in vitro model of the human small intestinal mucosa, in which epithelial cells were treated with LPS with or without prior challenge with resveratrol [219]. Among the genes found to be regulated by LPS but repressed by resveratrol were endothelial lipase, acyl-CoA synthetase, and many others involved in lipid synthesis and/or cholesterol handling. Furthermore, resveratrol has been reported to inhibit lipogenesis in rodent fat cells too, in 
an acute, short-term manner. Taking together these observations, it could be suggested that resveratrol can directly reduce the activity of enzymes involved in lipogenic pathways, in a concerted manner with the down-regulatory role it plays on their expression [143]. All these integrated actions of resveratrol limit LPS bacterial production and its consequences on epithelial transcript factors, reshape intestinal lipid metabolism, and lead to a reinforcement of the intestinal barrier when challenged by an excess of lipids. As a consequence of such modulation, the beneficial effects of ingested resveratrol or its metabolites before and after trans-epithelial absorption seemingly include changes in the intraluminal microbiota and SCFA levels, gut barrier integrity, and blood cholesterol and triglycerides.

Our second hypothesis is that the antioxidant properties of polyphenols can trigger pleiotropic responses in both the microbiota and the host. It is worthy to note that NADPH oxidase was upregulated by LPS but down-regulated by resveratrol in epithelial cells used in the abovementioned study [219]. NADPH oxidase is a complex membrane-bound enzyme implicated in the immune response, but it is also recognized as generating superoxides and ROS. Because of their antioxidant properties, resveratrol and its derivatives can potentially counteract the consequences of ROS produced by NADPH oxidase and other ROS-generating enzymes. In this sense, we recently confirmed that resveratrol impairs not only the fate of hydrogen peroxide generated by monoamide oxidase in fat cells but also the catalytic activity of the oxidase itself [143]. In bacteria, there are amine oxidases equivalent to those found in mammalian cells. Although their roles are not completely defined, it has been proposed that they are useful for survival in harsh culture conditions, allowing for diversification of the sources of nitrogen and provide a growth advantage over competing species (via the hydrogen peroxide they produce). Noteworthy, the deletion of the Escherichia coli copper amine oxidase (ECAO) has been demonstrated to alter the growth abilities of its associated strain, with significant metabolic changes [220]. Many other alterations have been reported among strains expressing (or not) ECAO and have led to this enzyme being characterized as capable of influencing bacterial growth and adhesion [220]. Thus, in addition to its well-known antimicrobial properties, resveratrol might reshape gut bacteria composition by counteracting ROS actions and inhibiting amine oxidase activities, thereby selecting given bacterial species. However, whether this potential mechanism is different from other dietary antioxidants and contributes to the specificity of the stilbenoid in reversing gut microbial dysbiosis remains to be elucidated.

As a final note, it is important to mention that differences in results among the studies discussed may be due to a variety of reasons: Species (mice vs. rats vs. humans) and disease model (knock-out, obese, etc.); a wide variety in dosage of resveratrol and duration of supplementation; the administration route (mixed in diet or drinking water, oral gavage); and the combination with other compounds (e.g. quercetin), making it difficult to dissect the effects of each. Furthermore, studies also differ in how they report the changes observed in gut microbiota composition, where differences are seen in either species, genus, and/or the phylum level, making it tricky to elucidate the impact of polyphenol-microbiota interactions in the first instance.

\section{Conclusions}

It is becoming clear that we are moving towards an era in which treatments and strategies, particularly nutritional interventions such as resveratrol supplementation, to counteract obesity and metabolic syndrome will need a personalized approach tailored to the individual in order to be as effective as possible. The gut microbiota composition is an important factor to consider in this equation. Further studies, together with growing knowledge on the role of gut microbiota composition, will inevitably provide exciting future directions, as in the case of resveratrol-based supplementations.

Author Contributions: Conceptualization, A.C. and J.M.; writing-original draft preparation, A.C. and J.M.; writing-review and editing, A.C., C.C. and J.M.

Funding: This research received no external funding.

Conflicts of Interest: The authors declare no conflict of interest. 


\section{References}

1. Huang, P.L. A comprehensive definition for metabolic syndrome. Dis. Model Mech. 2009, 2, $231-237$. [CrossRef] [PubMed]

2. Deedwania, P.C.; Gupta, R. Management issues in the metabolic syndrome. J. Assoc. Physic. India 2006, 54, 797-810.

3. Haghighatdoost, F.; Hariri, M. Effect of resveratrol on lipid profile: An updated systematic review and meta-analysis on randomized clinical trials. Pharmacol. Res. 2018, 129, 141-150. [CrossRef] [PubMed]

4. $\quad$ Lagouge, M.; Argmann, C.; Gerhart-Hines, Z.; Meziane, H.; Lerin, C.; Daussin, F.; Messadeq, N.; Milne, J.; Lambert, P.; Elliott, P.; et al. Resveratrol improves mitochondrial function and protects against metabolic disease by activating SIRT1 and PGC-1alpha. Cell 2006, 127, 1109-1122. [CrossRef] [PubMed]

5. Liu, Y.; Ma, W.; Zhang, P.; He, S.; Huang, D. Effect of resveratrol on blood pressure: A meta-analysis of randomized controlled trials. Clin. Nutr. 2015, 34, 27-34. [CrossRef] [PubMed]

6. Zhu, X.; Wu, C.; Qiu, S.; Yuan, X.; Li, L. Effects of resveratrol on glucose control and insulin sensitivity in subjects with type 2 diabetes: Systematic review and meta-analysis. Nutr. Metab. 2017, 14, 60. [CrossRef] [PubMed]

7. Haseeb, S.; Alexander, B.; Baranchuk, A. Wine and Cardiovascular Health: A Comprehensive Review. Circulation 2017, 136, 1434-1448. [CrossRef] [PubMed]

8. Baur, J.A.; Pearson, K.J.; Price, N.L.; Jamieson, H.A.; Lerin, C.; Kalra, A.; Prabhu, V.V.; Allard, J.S.; Lopez-Lluch, G.; Lewis, K.; et al. Resveratrol improves health and survival of mice on a high-calorie diet. Nature 2006, 444, 337-342. [CrossRef] [PubMed]

9. Fernández-Quintela, A.; Carpéné, C.; Fernández, M.; Aguirre, L.; Milton-Laskibar, I.; Contreras, J.; Portillo, M.P. Anti-obesity effects of resveratrol: Comparison between animal models and humans. J. Physiol. Biochem. 2016, 73, 417-429. [CrossRef] [PubMed]

10. Bode, L.M.; Bunzel, D.; Huch, M.; Cho, G.S.; Ruhland, D.; Bunzel, M.; Bub, A.; Franz, C.M.; Kulling, S.E. In vivo and in vitro metabolism of trans-resveratrol by human gut microbiota. Am. J. Clin. Nutr. 2013, 97, 295-309. [CrossRef] [PubMed]

11. Theilmann, M.C.; Goh, Y.J.; Nielsen, K.F.; Klaenhammer, T.R.; Barrangou, R.; Abou Hachem, M. Metabolizes dietary plant glucosides and externalizes their bioactive phytochemicals. MBio 2017. [CrossRef] [PubMed]

12. Carrera-Quintanar, L.; López Roa, R.I.; Quintero-Fabián, S.; Sánchez-Sánchez, M.A.; Vizmanos, B.; Ortuño-Sahagún, D. Phytochemicals that influence gut microbiota as prophylactics and for the treatment of obesity and inflammatory diseases. Mediators Inflamm. 2018, 2018, 9734845. [CrossRef] [PubMed]

13. Gambini, J.; Inglés, M.; Olaso, G.; Lopez-Grueso, R.; Bonet-Costa, V.; Gimeno-Mallench, L.; Mas-Bargues, C.; Abdelaziz, K.M.; Gomez-Cabrera, M.C.; Vina, J.; et al. Properties of resveratrol: In vitro and in vivo studies about metabolism, bioavailability, and biological effects in animal models and humans. Oxid. Med. Cell Longev. 2015, 2015, 837042. [CrossRef] [PubMed]

14. Walle, T. Bioavailability of resveratrol. Ann. N. Y. Acad. Sci. 2011, 1215, 9-15. [CrossRef] [PubMed]

15. Bresciani, L.; Calani, L.; Bocchi, L.; Delucchi, F.; Savi, M.; Ray, S.; Brighenti, F.; Stilli, D.; Del Rio, D. Bioaccumulation of resveratrol metabolites in myocardial tissue is dose-time dependent and related to cardiac hemodynamics in diabetic rats. Nutr. Metab. Cardiovasc. Dis. 2014, 24, 408-415. [CrossRef] [PubMed]

16. Andres-Lacueva, C.; Macarulla, M.T.; Rotches-Ribalta, M.; Boto-Ordóñez, M.; Urpi-Sarda, M.; Rodríguez, V.M.; Portillo, M.P. Distribution of resveratrol metabolites in liver, adipose tissue, and skeletal muscle in rats fed different doses of this polyphenol. J. Agric. Food Chem. 2012, 60, 4833-4840. [CrossRef] [PubMed]

17. Menet, M.C.; Baron, S.; Taghi, M.; Diestra, R.; Dargère, D.; Laprévote, O.; Nivet-Antoine, V.; Beaudeux, J.L.; Bédarida, T.; Cottart, C.H. Distribution of trans-resveratrol and its metabolites after acute or sustained administration in mouse heart, brain, and liver. Mol. Nutr. Food Res. 2017. [CrossRef] [PubMed]

18. Potter, G.A.; Patterson, L.H.; Wanogho, E.; Perry, P.J.; Butler, P.C.; Ijaz, T.; Ruparelia, K.C.; Lamb, J.H.; Farmer, P.B.; Stanley, L.A.; et al. The cancer preventative agent resveratrol is converted to the anticancer agent piceatannol by the cytochrome P450 enzyme CYP1B1. Br. J. Cancer 2002, 86, 774-778. [CrossRef] [PubMed]

19. Kershaw, J.; Kim, K.H. The Therapeutic Potential of Piceatannol, a Natural Stilbene, in Metabolic Diseases: A Review. J. Med. Food 2017, 20, 427-438. [CrossRef] [PubMed] 
20. Rotches-Ribalta, M.; Urpi-Sarda, M.; Llorach, R.; Boto-Ordoñez, M.; Jauregui, O.; Chiva-Blanch, G.; Perez-Garcia, L.; Jaeger, W.; Guillen, M.; Corella, D.; et al. Gut and microbial resveratrol metabolite profiling after moderate long-term consumption of red wine versus dealcoholized red wine in humans by an optimized ultra-high-pressure liquid chromatography tandem mass spectrometry method. J. Chromatogr. A 2012, 1265, 105-113. [CrossRef] [PubMed]

21. Basholli-Salihu, M.; Schuster, R.; Mulla, D.; Praznik, W.; Viernstein, H.; Mueller, M. Bioconversion of piceid to resveratrol by selected probiotic cell extracts. Bioprocess Biosyst. Eng. 2016, 39, 1879-1885. [CrossRef] [PubMed]

22. Wang, D.; Zhang, Z.; Ju, J.; Wang, X.; Qiu, W. Investigation of piceid metabolites in rat by liquid chromatography tandem mass spectrometry. J. Chromatogr. B. Anal. Technol. Biomed. Life Sci. 2011, 879, 69-74. [CrossRef] [PubMed]

23. Rotches-Ribalta, M.; Andres-Lacueva, C.; Estruch, R.; Escribano, E.; Urpi-Sarda, M. Pharmacokinetics of resveratrol metabolic profile in healthy humans after moderate consumption of red wine and grape extract tablets. Pharmacol. Res. 2012, 66, 375-382. [CrossRef] [PubMed]

24. Macarulla, M.T.; Alberdi, G.; Gómez, S.; Tueros, I.; Bald, C.; Rodríguez, V.M.; Martínez, J.A.; Portillo, M.P. Effects of different doses of resveratrol on body fat and serum parameters in rats fed a hypercaloric diet. J. Physiol. Biochem. 2009, 65, 369-376. [CrossRef] [PubMed]

25. Kim, S.; Jin, Y.; Choi, Y.; Park, T. Resveratrol exerts anti-obesity effects via mechanisms involving down-regulation of adipogenic and inflammatory processes in mice. Biochem. Pharmacol. 2011, 81, 1343-1351. [CrossRef] [PubMed]

26. Cho, S.J.; Jung, U.J.; Choi, M.S. Differential effects of low-dose resveratrol on adiposity and hepatic steatosis in diet-induced obese mice. Br. J. Nutr. 2012, 108, 2166-2175. [CrossRef] [PubMed]

27. Picard, F.; Kurtev, M.; Chung, N.; Topark-Ngarm, A.; Senawong, T.; Machado De Oliveira, R.; Leid, M.; McBurney, M.W.; Guarente, L. Sirt1 promotes fat mobilization in white adipocytes by repressing PPAR-gamma. Nature 2004, 429, 771-776. [CrossRef] [PubMed]

28. Park, S.J.; Ahmad, F.; Philp, A.; Baar, K.; Williams, T.; Luo, H.; Ke, H.; Rehmann, H.; Taussig, R.; Brown, A.L.; et al. Resveratrol ameliorates aging-related metabolic phenotypes by inhibiting cAMP phosphodiesterases. Cell 2012, 148, 421-433. [CrossRef] [PubMed]

29. Gracia, A.; Miranda, J.; Fernández-Quintela, A.; Eseberri, I.; Garcia-Lacarte, M.; Milagro, F.I.; Martínez, J.A.; Aguirre, L.; Portillo, M.P. Involvement of miR-539-5p in the inhibition of de novo lipogenesis induced by resveratrol in white adipose tissue. Food Funct. 2016, 7, 1680-1688. [CrossRef] [PubMed]

30. Fischer-Posovszky, P.; Kukulus, V.; Tews, D.; Unterkircher, T.; Debatin, K.M.; Fulda, S.; Wabitsch, M. Resveratrol regulates human adipocyte number and function in a Sirt1-dependent manner. Am. J. Clin. Nutr. 2010, 92, 5-15. [CrossRef] [PubMed]

31. Hsu, C.L.; Yen, G.C. Induction of cell apoptosis in 3T3-L1 pre-adipocytes by flavonoids is associated with their antioxidant activity. Mol. Nutr. Food Res. 2006, 50, 1072-1079. [CrossRef] [PubMed]

32. Arzola-Paniagua, M.A.; García-Salgado López, E.R.; Calvo-Vargas, C.G.; Guevara-Cruz, M. Efficacy of an orlistat-resveratrol combination for weight loss in subjects with obesity: A randomized controlled trial. Obesity 2016, 24, 1454-1463. [CrossRef] [PubMed]

33. Mercader, J.; Palou, A.; Bonet, M.L. Resveratrol enhances fatty acid oxidation capacity and reduces resistin and Retinol-Binding Protein 4 expression in white adipocytes. J. Nutr. Biochem. 2011, 22, 828-834. [CrossRef] [PubMed]

34. Wang, S.; Liang, X.; Yang, Q.; Fu, X.; Rogers, C.J.; Zhu, M.; Rodgers, B.D.; Jiang, Q.; Dodson, M.V.; Du, M. Resveratrol induces brown-like adipocyte formation in white fat through activation of AMP-activated protein kinase (AMPK) $\alpha 1$. Int. J. Obes. 2015, 39, 967-976. [CrossRef] [PubMed]

35. Gomez-Zorita, S.; Tréguer, K.; Mercader, J.; Carpéné, C. Resveratrol directly affects in vitro lipolysis and glucose transport in human fat cells. J. Physiol. Biochem. 2013, 69, 585-593. [CrossRef] [PubMed]

36. Wang, S.; Liang, X.; Yang, Q.; Fu, X.; Zhu, M.; Rodgers, B.D.; Jiang, Q.; Dodson, M.V.; Du, M. Resveratrol enhances brown adipocyte formation and function by activating AMP-activated protein kinase (AMPK) $\alpha 1$ in mice fed high-fat diet. Mol. Nutr. Food Res. 2017. [CrossRef] [PubMed]

37. Lasa, A.; Schweiger, M.; Kotzbeck, P.; Churruca, I.; Simón, E.; Zechner, R.; Portillo, M.P. Resveratrol regulates lipolysis via adipose triglyceride lipase. J. Nutr. Biochem. 2012, 23, 379-384. [CrossRef] [PubMed] 
38. Alberdi, G.; Rodríguez, V.M.; Miranda, J.; Macarulla, M.T.; Arias, N.; Andrés-Lacueva, C.; Portillo, M.P. Changes in white adipose tissue metabolism induced by resveratrol in rats. Nutr. Metab. 2011, 8, 29. [CrossRef] [PubMed]

39. Alberdi, G.; Rodríguez, V.M.; Miranda, J.; Macarulla, M.T.; Churruca, I.; Portillo, M.P. Thermogenesis is involved in the body-fat lowering effects of resveratrol in rats. Food Chem. 2013, 141, 1530-1535. [CrossRef] [PubMed]

40. Poulsen, M.M.; Vestergaard, P.F.; Clasen, B.F.; Radko, Y.; Christensen, L.P.; Stødkilde-Jørgensen, H.; Møller, N.; Jessen, N.; Pedersen, S.B.; Jørgensen, J.O. High-dose resveratrol supplementation in obese men: An investigator-initiated, randomized, placebo-controlled clinical trial of substrate metabolism, insulin sensitivity, and body composition. Diabetes 2013, 62, 1186-1195. [CrossRef] [PubMed]

41. Timmers, S.; Konings, E.; Bilet, L.; Houtkooper, R.H.; van de Weijer, T.; Goossens, G.H.; Hoeks, J.; van der Krieken, S.; Ryu, D.; Kersten, S.; et al. Calorie restriction-like effects of 30 days of resveratrol supplementation on energy metabolism and metabolic profile in obese humans. Cell Metab. 2011, 14, 612-622. [CrossRef] [PubMed]

42. Konings, E.; Timmers, S.; Boekschoten, M.V.; Goossens, G.H.; Jocken, J.W.; Afman, L.A.; Müller, M.; Schrauwen, P.; Mariman, E.C.; Blaak, E.E. The effects of 30 days resveratrol supplementation on adipose tissue morphology and gene expression patterns in obese men. Int. J. Obes. 2014, 38, 470-473. [CrossRef] [PubMed]

43. Kjær, T.N.; Ornstrup, M.J.; Poulsen, M.M.; Stødkilde-Jørgensen, H.; Jessen, N.; Jørgensen, J.O.L.; Richelsen, B.; Pedersen, S.B. No Beneficial Effects of Resveratrol on the Metabolic Syndrome: A Randomized Placebo-Controlled Clinical Trial. J. Clin. Endocrinol. Metab. 2017, 102, 1642-1651. [CrossRef] [PubMed]

44. Méndez-del Villar, M.; González-Ortiz, M.; Martínez-Abundis, E.; Pérez-Rubio, K.G.; Lizárraga-Valdez, R. Effect of resveratrol administration on metabolic syndrome, insulin sensitivity, and insulin secretion. Metab. Syndr. Relat. Disord. 2014, 12, 497-501. [CrossRef] [PubMed]

45. Chachay, V.S.; Macdonald, G.A.; Martin, J.H.; Whitehead, J.P.; O’Moore-Sullivan, T.M.; Lee, P.; Franklin, M.; Klein, K.; Taylor, P.J.; Ferguson, M.; et al. Resveratrol does not benefit patients with nonalcoholic fatty liver disease. Clin. Gastroenterol. Hepatol. 2014, 12, 2092-2103. [CrossRef] [PubMed]

46. Faghihzadeh, F.; Adibi, P.; Hekmatdoost, A. The effects of resveratrol supplementation on cardiovascular risk factors in patients with non-alcoholic fatty liver disease: A randomised, double-blind, placebo-controlled study. Br. J. Nutr. 2015, 114, 796-803. [CrossRef] [PubMed]

47. Thazhath, S.S.; Wu, T.; Bound, M.J.; Checklin, H.L.; Standfield, S.; Jones, K.L.; Horowitz, M.; Rayner, C.K. Administration of resveratrol for $5 \mathrm{wk}$ has no effect on glucagon-like peptide 1 secretion, gastric emptying, or glycemic control in type 2 diabetes: A randomized controlled trial. Am. J. Clin. Nutr. 2016, 103, 66-70. [CrossRef] [PubMed]

48. Bo, S.; Ponzo, V.; Ciccone, G.; Evangelista, A.; Saba, F.; Goitre, I.; Procopio, M.; Pagano, G.F.; Cassader, M.; Gambino, R. Six months of resveratrol supplementation has no measurable effect in type 2 diabetic patients. A randomized, double blind, placebo-controlled trial. Pharmacol. Res. 2016, 111, 896-905. [CrossRef] [PubMed]

49. Most, J.; Timmers, S.; Warnke, I.; Jocken, J.W.; van Boekschoten, M.; de Groot, P.; Bendik, I.; Schrauwen, P.; Goossens, G.H.; Blaak, E.E. Combined epigallocatechin-3-gallate and resveratrol supplementation for $12 \mathrm{wk}$ increases mitochondrial capacity and fat oxidation, but not insulin sensitivity, in obese humans: A randomized controlled trial. Am. J. Clin. Nutr. 2016, 104, 215-227. [CrossRef] [PubMed]

50. Poulsen, M.M.; Larsen, J.; Hamilton-Dutoit, S.; Clasen, B.F.; Jessen, N.; Paulsen, S.K.; Kjær, T.N.; Richelsen, B.; Pedersen, S.B. Resveratrol up-regulates hepatic uncoupling protein 2 and prevents development of nonalcoholic fatty liver disease in rats fed a high-fat diet. Nutr. Res. 2012, 32, 701-708. [CrossRef] [PubMed]

51. Alberdi, G.; Rodríguez, V.M.; Macarulla, M.T.; Miranda, J.; Churruca, I.; Portillo, M.P. Hepatic lipid metabolic pathways modified by resveratrol in rats fed an obesogenic diet. Nutrition 2013, 29, 562-567. [CrossRef] [PubMed]

52. Bujanda, L.; Hijona, E.; Larzabal, M.; Beraza, M.; Aldazabal, P.; García-Urkia, N.; Sarasqueta, C.; Cosme, A.; Irastorza, B.; González, A.; et al. Resveratrol inhibits nonalcoholic fatty liver disease in rats. BMC Gastroenterol. 2008, 8, 40. [CrossRef] [PubMed] 
53. Gómez-Zorita, S.; Fernández-Quintela, A.; Macarulla, M.T.; Aguirre, L.; Hijona, E.; Bujanda, L.; Milagro, F.; Martínez, J.A.; Portillo, M.P. Resveratrol attenuates steatosis in obese Zucker rats by decreasing fatty acid availability and reducing oxidative stress. Br. J. Nutr. 2012, 107, 202-210. [CrossRef] [PubMed]

54. Andrade, J.M.; Paraíso, A.F.; de Oliveira, M.V.; Martins, A.M.; Neto, J.F.; Guimarães, A.L.; de Paula, A.M.; Qureshi, M.; Santos, S.H. Resveratrol attenuates hepatic steatosis in high-fat fed mice by decreasing lipogenesis and inflammation. Nutrition 2014, 30, 915-919. [CrossRef] [PubMed]

55. Pan, Q.R.; Ren, Y.L.; Liu, W.X.; Hu, Y.J.; Zheng, J.S.; Xu, Y.; Wang, G. Resveratrol prevents hepatic steatosis and endoplasmic reticulum stress and regulates the expression of genes involved in lipid metabolism, insulin resistance, and inflammation in rats. Nutr. Res. 2015, 35, 576-584. [CrossRef] [PubMed]

56. Elgebaly, A.; Radwan, I.A.; AboElnas, M.M.; Ibrahim, H.H.; Eltoomy, M.F.; Atta, A.A.; Mesalam, H.A.; Sayed, A.A.; Othman, A.A. Resveratrol supplementation in patients with non-alcoholic fatty liver disease: systematic review and meta-analysis. J. Gastrointestin. Liver Dis. 2017, 26, 59-67. [PubMed]

57. Zhang, C.; Yuan, W.; Fang, J.; Wang, W.; He, P.; Lei, J.; Wang, C. Efficacy of Resveratrol Supplementation against Non-Alcoholic Fatty Liver Disease: A Meta-Analysis of Placebo-Controlled Clinical Trials. PLoS ONE 2016, 11, e0161792. [CrossRef] [PubMed]

58. Timmers, S.; de Ligt, M.; Phielix, E.; van de Weijer, T.; Hansen, J.; Moonen-Kornips, E.; Schaart, G.; Kunz, I.; Hesselink, M.K.; Schrauwen-Hinderling, V.B.; et al. Resveratrol as Add-on Therapy in Subjects With Well-Controlled Type 2 Diabetes: A Randomized Controlled Trial. Diabetes Care 2016, 39, 2211-2217. [CrossRef] [PubMed]

59. Kang, L.; Heng, W.; Yuan, A.; Baolin, L.; Fang, H. Resveratrol modulates adipokine expression and improves insulin sensitivity in adipocytes: Relative to inhibition of inflammatory responses. Biochimie 2010, 92, 789-796. [CrossRef] [PubMed]

60. Kang, W.; Hong, H.J.; Guan, J.; Kim, D.G.; Yang, E.J.; Koh, G.; Park, D.; Han, C.H.; Lee, Y.J.; Lee, D.H. Resveratrol improves insulin signaling in a tissue-specific manner under insulin-resistant conditions only: In vitro and in vivo experiments in rodents. Metabolism 2012, 61, 424-433. [CrossRef] [PubMed]

61. Costa, C.o.S.; Rohden, F.; Hammes, T.O.; Margis, R.; Bortolotto, J.W.; Padoin, A.V.; Mottin, C.C.; Guaragna, R.M. Resveratrol upregulated SIRT1, FOXO1, and adiponectin and downregulated PPAR $\gamma 1-3$ mRNA expression in human visceral adipocytes. Obes. Surg. 2011, 21, 356-361. [CrossRef] [PubMed]

62. Bagul, P.K.; Middela, H.; Matapally, S.; Padiya, R.; Bastia, T.; Madhusudana, K.; Reddy, B.R.; Chakravarty, S.; Banerjee, S.K. Attenuation of insulin resistance, metabolic syndrome and hepatic oxidative stress by resveratrol in fructose-fed rats. Pharmacol. Res. 2012, 66, 260-268. [CrossRef] [PubMed]

63. Kitada, M.; Kume, S.; Imaizumi, N.; Koya, D. Resveratrol improves oxidative stress and protects against diabetic nephropathy through normalization of Mn-SOD dysfunction in AMPK/SIRT1-independent pathway. Diabetes 2011, 60, 634-643. [CrossRef] [PubMed]

64. Palsamy, P.; Subramanian, S. Resveratrol protects diabetic kidney by attenuating hyperglycemia-mediated oxidative stress and renal inflammatory cytokines via Nrf2-Keap1 signaling. Biochim. Biophys. Acta. 2011, 1812, 719-731. [CrossRef] [PubMed]

65. Chang, C.C.; Chang, C.Y.; Wu, Y.T.; Huang, J.P.; Yen, T.H.; Hung, L.M. Resveratrol retards progression of diabetic nephropathy through modulations of oxidative stress, proinflammatory cytokines, and AMP-activated protein kinase. J. Biomed. Sci. 2011, 18, 47. [CrossRef] [PubMed]

66. Öztürk, E.; Arslan, A.K.K.; Yerer, M.B.; Bishayee, A. Resveratrol and diabetes: A critical review of clinical studies. Biomed. Pharmacother. 2017, 95, 230-234. [CrossRef] [PubMed]

67. Van der Made, S.M.; Plat, J.; Mensink, R.P. Resveratrol does not influence metabolic risk markers related to cardiovascular health in overweight and slightly obese subjects: A randomized, placebo-controlled crossover trial. PLoS ONE 2015, 10, e0118393. [CrossRef] [PubMed]

68. Dash, S.; Xiao, C.; Morgantini, C.; Szeto, L.; Lewis, G.F. High-dose resveratrol treatment for 2 weeks inhibits intestinal and hepatic lipoprotein production in overweight/obese men. Arterioscler. Thromb. Vasc. Biol. 2013, 33, 2895-2901. [CrossRef] [PubMed]

69. Yoshino, J.; Conte, C.; Fontana, L.; Mittendorfer, B.; Imai, S.; Schechtman, K.B.; Gu, C.; Kunz, I.; Rossi Fanelli, F.; Patterson, B.W.; et al. Resveratrol supplementation does not improve metabolic function in nonobese women with normal glucose tolerance. Cell Metab. 2012, 16, 658-664. [CrossRef] [PubMed] 
70. Knop, F.K.; Konings, E.; Timmers, S.; Schrauwen, P.; Holst, J.J.; Blaak, E.E. Thirty days of resveratrol supplementation does not affect postprandial incretin hormone responses, but suppresses postprandial glucagon in obese subjects. Diabet. Med. 2013, 30, 1214-1218. [CrossRef] [PubMed]

71. Pollack, R.M.; Barzilai, N.; Anghel, V.; Kulkarni, A.S.; Golden, A.; O’Broin, P.; Sinclair, D.A.; Bonkowski, M.S.; Coleville, A.J.; Powell, D.; et al. Resveratrol improves vascular function and mitochondrial number but not glucose metabolism in older adults. J. Gerontol. A Biol. Sci. Med. Sci. 2017, 72, 1703-1709. [CrossRef] [PubMed]

72. Bhatt, J.K.; Thomas, S.; Nanjan, M.J. Resveratrol supplementation improves glycemic control in type 2 diabetes mellitus. Nutr. Res. 2012, 32, 537-541. [CrossRef] [PubMed]

73. Brasnyó, P.; Molnár, G.A.; Mohás, M.; Markó, L.; Laczy, B.; Cseh, J.; Mikolás, E.; Szijártó, I.A.; Mérei, A.; Halmai, R.; et al. Resveratrol improves insulin sensitivity, reduces oxidative stress and activates the Akt pathway in type 2 diabetic patients. Br. J. Nutr. 2011, 106, 383-389. [CrossRef] [PubMed]

74. Zare Javid, A.; Hormoznejad, R.; Yousefimanesh, H.A.; Zakerkish, M.; Haghighi-Zadeh, M.H.; Dehghan, P.; Ravanbakhsh, M. The impact of resveratrol supplementation on blood glucose, insulin, insulin resistance, triglyceride, and periodontal markers in type 2 diabetic patients with chronic periodontitis. Phytother. Res. 2017, 31, 108-114. [CrossRef] [PubMed]

75. Crandall, J.P.; Oram, V.; Trandafirescu, G.; Reid, M.; Kishore, P.; Hawkins, M.; Cohen, H.W.; Barzilai, N. Pilot study of resveratrol in older adults with impaired glucose tolerance. J. Gerontol. A Biol. Sci. Med. Sci. 2012, 67, 1307-1312. [CrossRef] [PubMed]

76. Chen, S.; Zhao, X.; Ran, L.; Wan, J.; Wang, X.; Qin, Y.; Shu, F.; Gao, Y.; Yuan, L.; Zhang, Q.; et al. Resveratrol improves insulin resistance, glucose and lipid metabolism in patients with non-alcoholic fatty liver disease: A randomized controlled trial. Dig. Liver Dis. 2015, 47, 226-232. [CrossRef] [PubMed]

77. Liu, K.; Zhou, R.; Wang, B.; Mi, M.T. Effect of resveratrol on glucose control and insulin sensitivity: A meta-analysis of 11 randomized controlled trials. Am. J. Clin. Nutr. 2014, 99, 1510-1519. [CrossRef] [PubMed]

78. Hausenblas, H.A.; Schoulda, J.A.; Smoliga, J.M. Resveratrol treatment as an adjunct to pharmacological management in type 2 diabetes mellitus-systematic review and meta-analysis. Mol. Nutr. Food Res. 2015, 59, 147-159. [CrossRef] [PubMed]

79. Szkudelski, T.; Szkudelska, K. Resveratrol and diabetes: From animal to human studies. Biochim. Biophys. Acta. 2015, 1852, 1145-1154. [CrossRef] [PubMed]

80. Mozafari, M.; Nekooeian, A.A.; Panjeshahin, M.R.; Zare, H.R. The effects of resveratrol in rats with simultaneous type 2 diabetes and renal hypertension: A study of antihypertensive mechanisms. Iran. J. Med. Sci. 2015, 40, 152-160. [PubMed]

81. Gordish, K.L.; Beierwaltes, W.H. Chronic resveratrol reverses a mild angiotensin II-induced pressor effect in a rat model. Integr. Blood Press Control 2016, 9, 23-31. [PubMed]

82. Cheng, P.W.; Ho, W.Y.; Su, Y.T.; Lu, P.J.; Chen, B.Z.; Cheng, W.H.; Lu, W.H.; Sun, G.C.; Yeh, T.C.; Hsiao, M.; et al. Resveratrol decreases fructose-induced oxidative stress, mediated by NADPH oxidase via an AMPK-dependent mechanism. Br. J. Pharmacol. 2014, 171, 2739-2750. [CrossRef] [PubMed]

83. Yu, L.; Tu, Y.; Jia, X.; Fang, K.; Liu, L.; Wan, L.; Xiang, C.; Wang, Y.; Sun, X.; Liu, T.; et al. Resveratrol protects against pulmonary arterial hypertension in rats via activation of silent information regulator 1. Cell Physiol. Biochem. 2017, 42, 55-67. [CrossRef] [PubMed]

84. Heebøll, S.; Kreuzfeldt, M.; Hamilton-Dutoit, S.; Kjær Poulsen, M.; Stødkilde-Jørgensen, H.; Møller, H.J.; Jessen, N.; Thorsen, K.; Kristina Hellberg, Y.; Bønløkke Pedersen, S.; et al. Placebo-controlled, randomised clinical trial: High-dose resveratrol treatment for non-alcoholic fatty liver disease. Scand. J. Gastroenterol. 2016, 51, 456-464. [CrossRef] [PubMed]

85. Imamura, H.; Yamaguchi, T.; Nagayama, D.; Saiki, A.; Shirai, K.; Tatsuno, I. Resveratrol ameliorates arterial stiffness assessed by cardio-ankle vascular index in patients with type 2 diabetes mellitus. Int. Heart J. 2017, 58, 577-583. [CrossRef] [PubMed]

86. Wong, R.H.; Berry, N.M.; Coates, A.M.; Buckley, J.D.; Bryan, J.; Kunz, I.; Howe, P.R. Chronic resveratrol consumption improves brachial flow-mediated dilatation in healthy obese adults. J. Hypertens. 2013, 31, 1819-1827. [CrossRef] [PubMed] 
87. Sahebkar, A.; Serban, C.; Ursoniu, S.; Wong, N.D.; Muntner, P.; Graham, I.M.; Mikhailidis, D.P.; Rizzo, M.; Rysz, J.; Sperling, L.S.; et al. Lack of efficacy of resveratrol on C-reactive protein and selected cardiovascular risk factors-Results from a systematic review and meta-analysis of randomized controlled trials. Int. J. Cardiol. 2015, 189, 47-55. [CrossRef] [PubMed]

88. Huang, H.; Chen, G.; Liao, D.; Zhu, Y.; Pu, R.; Xue, X. The effects of resveratrol intervention on risk markers of cardiovascular health in overweight and obese subjects: A pooled analysis of randomized controlled trials. Obes. Rev. 2016, 17, 1329-1340. [CrossRef] [PubMed]

89. Fogacci, F.; Tocci, G.; Presta, V.; Fratter, A.; Borghi, C.; Cicero, A.F.G. Effect of resveratrol on blood pressure: A systematic review and meta-analysis of randomized, controlled, clinical trials. Crit. Rev. Food Sci. Nutr. 2018. [CrossRef] [PubMed]

90. Marques, B.C.A.A.; Trindade, M.; Aquino, J.C.F.; Cunha, A.R.; Gismondi, R.O.; Neves, M.F.; Oigman, W. Beneficial effects of acute trans-resveratrol supplementation in treated hypertensive patients with endothelial dysfunction. Clin. Exp. Hypertens. 2018, 40, 218-223. [CrossRef] [PubMed]

91. Wong, R.H.; Howe, P.R.; Buckley, J.D.; Coates, A.M.; Kunz, I.; Berry, N.M. Acute resveratrol supplementation improves flow-mediated dilatation in overweight/obese individuals with mildly elevated blood pressure. Nutr. Metab. Cardiovasc. Dis. 2011, 21, 851-856. [CrossRef] [PubMed]

92. Gnoni, G.V.; Paglialonga, G. Resveratrol inhibits fatty acid and triacylglycerol synthesis in rat hepatocytes. Eur. J. Clin. Invest. 2009, 39, 211-218. [CrossRef] [PubMed]

93. Zern, T.L.; Wood, R.J.; Greene, C.; West, K.L.; Liu, Y.; Aggarwal, D.; Shachter, N.S.; Fernandez, M.L. Grape polyphenols exert a cardioprotective effect in pre- and postmenopausal women by lowering plasma lipids and reducing oxidative stress. J. Nutr. 2005, 135, 1911-1917. [CrossRef] [PubMed]

94. Qureshi, A.A.; Khan, D.A.; Mahjabeen, W.; Papasian, C.J.; Qureshi, N. Suppression of nitric oxide production and cardiovascular risk factors in healthy seniors and hypercholesterolemic subjects by a combination of polyphenols and vitamins. J. Clin. Exp. Cardiolog. 2012. [CrossRef]

95. Simental-Mendía, L.E.; Guerrero-Romero, F. Effect of resveratrol supplementation on lipid profile in subjects with dyslipidemia: A randomized double-blind, placebo-controlled trial. Nutrition 2018, 58, 7-10. [CrossRef] [PubMed]

96. Shao, D.; Wang, Y.; Huang, Q.; Shi, J.; Yang, H.; Pan, Z.; Jin, M.; Zhao, H.; Xu, X. Cholesterol-lowering effects and mechanisms in view of bile acid pathway of resveratrol and resveratrol glucuronides. J. Food Sci. 2016, 81, H2841-H2848. [CrossRef] [PubMed]

97. Chen, Q.; Wang, E.; Ma, L.; Zhai, P. Dietary resveratrol increases the expression of hepatic $7 \alpha$-hydroxylase and ameliorates hypercholesterolemia in high-fat fed C57BL/6J mice. Lipids Health Dis. 2012, 11, 56. [CrossRef] [PubMed]

98. Berrougui, H.; Grenier, G.; Loued, S.; Drouin, G.; Khalil, A. A new insight into resveratrol as an atheroprotective compound: Inhibition of lipid peroxidation and enhancement of cholesterol efflux. Atherosclerosis 2009, 207, 420-427. [CrossRef] [PubMed]

99. Tomé-Carneiro, J.; Gonzálvez, M.; Larrosa, M.; García-Almagro, F.J.; Avilés-Plaza, F.; Parra, S.; Yáñez-Gascón, M.J.; Ruiz-Ros, J.A.; García-Conesa, M.T.; Tomás-Barberán, F.A.; et al. Consumption of a grape extract supplement containing resveratrol decreases oxidized LDL and ApoB in patients undergoing primary prevention of cardiovascular disease: A triple-blind, 6-month follow-up, placebo-controlled, randomized trial. Mol. Nutr. Food Res. 2012, 56, 810-821. [CrossRef] [PubMed]

100. Dvorakova, M.; Landa, P. Anti-inflammatory activity of natural stilbenoids: A review. Pharmacol. Res. 2017, 124, 126-145. [CrossRef] [PubMed]

101. Latruffe, N.; Lançon, A.; Frazzi, R.; Aires, V.; Delmas, D.; Michaille, J.J.; Djouadi, F.; Bastin, J.; Cherkaoui-Malki, M. Exploring new ways of regulation by resveratrol involving miRNAs, with emphasis on inflammation. Ann. N. Y. Acad. Sci. 2015, 1348, 97-106. [CrossRef] [PubMed]

102. Zhu, J.; Yong, W.; Wu, X.; Yu, Y.; Lv, J.; Liu, C.; Mao, X.; Zhu, Y.; Xu, K.; Han, X. Anti-inflammatory effect of resveratrol on TNF-alpha-induced MCP-1 expression in adipocytes. Biochem. Biophys. Res. Commun. 2008, 369, 471-477. [CrossRef] [PubMed]

103. Olholm, J.; Paulsen, S.K.; Cullberg, K.B.; Richelsen, B.; Pedersen, S.B. Anti-inflammatory effect of resveratrol on adipokine expression and secretion in human adipose tissue explants. Int. J. Obes. 2010, 34, 1546-1553. [CrossRef] [PubMed] 
104. Yen, G.C.; Chen, Y.C.; Chang, W.T.; Hsu, C.L. Effects of polyphenolic compounds on tumor necrosis factor- $\alpha$ (TNF- $\alpha$ )-induced changes of adipokines and oxidative stress in 3T3-L1 adipocytes. J. Agric. Food Chem. 2011, 59, 546-551. [CrossRef] [PubMed]

105. Gonzales, A.M.; Orlando, R.A. Curcumin and resveratrol inhibit nuclear factor-kappaB-mediated cytokine expression in adipocytes. Nutr. Metab. 2008, 5, 17. [CrossRef] [PubMed]

106. Cullberg, K.B.; Olholm, J.; Paulsen, S.K.; Foldager, C.B.; Lind, M.; Richelsen, B.; Pedersen, S.B. Resveratrol has inhibitory effects on the hypoxia-induced inflammation and angiogenesis in human adipose tissue in vitro. Eur. J. Pharm. Sci. 2013, 49, 251-257. [CrossRef] [PubMed]

107. Tran, H.T.; Liong, S.; Lim, R.; Barker, G.; Lappas, M. Resveratrol ameliorates the chemical and microbial induction of inflammation and insulin resistance in human placenta, adipose tissue and skeletal muscle. PLoS ONE 2017, 12, e0173373. [CrossRef] [PubMed]

108. Gómez-Zorita, S.; Fernández-Quintela, A.; Lasa, A.; Hijona, E.; Bujanda, L.; Portillo, M.P. Effects of resveratrol on obesity-related inflammation markers in adipose tissue of genetically obese rats. Nutrition 2013, 29, 1374-1380. [CrossRef] [PubMed]

109. Jeon, B.T.; Jeong, E.A.; Shin, H.J.; Lee, Y.; Lee, D.H.; Kim, H.J.; Kang, S.S.; Cho, G.J.; Choi, W.S.; Roh, G.S. Resveratrol attenuates obesity-associated peripheral and central inflammation and improves memory deficit in mice fed a high-fat diet. Diabetes 2012, 61, 1444-1454. [CrossRef] [PubMed]

110. Wang, B.; Sun, J.; Li, X.; Zhou, Q.; Bai, J.; Shi, Y.; Le, G. Resveratrol prevents suppression of regulatory T-cell production, oxidative stress, and inflammation of mice prone or resistant to high-fat diet-induced obesity. Nutr. Res. 2013, 33, 971-981. [CrossRef] [PubMed]

111. Jimenez-Gomez, Y.; Mattison, J.A.; Pearson, K.J.; Martin-Montalvo, A.; Palacios, H.H.; Sossong, A.M.; Ward, T.M.; Younts, C.M.; Lewis, K.; Allard, J.S.; et al. Resveratrol improves adipose insulin signaling and reduces the inflammatory response in adipose tissue of rhesus monkeys on high-fat, high-sugar diet. Cell Metab. 2013, 18, 533-545. [CrossRef] [PubMed]

112. Wang, B.; Sun, J.; Li, L.; Zheng, J.; Shi, Y.; Le, G. Regulatory effects of resveratrol on glucose metabolism and T-lymphocyte subsets in the development of high-fat diet-induced obesity in C57BL/6 mice. Food Funct. 2014, 5, 1452-1463. [CrossRef] [PubMed]

113. Ghanim, H.; Sia, C.L.; Korzeniewski, K.; Lohano, T.; Abuaysheh, S.; Marumganti, A.; Chaudhuri, A.; Dandona, P. A resveratrol and polyphenol preparation suppresses oxidative and inflammatory stress response to a high-fat, high-carbohydrate meal. J. Clin. Endocrinol. Metab. 2011, 96, 1409-1414. [CrossRef] [PubMed]

114. Tomé-Carneiro, J.; Larrosa, M.; Yáñez-Gascón, M.J.; Dávalos, A.; Gil-Zamorano, J.; Gonzálvez, M.; García-Almagro, F.J.; Ruiz Ros, J.A.; Tomás-Barberán, F.A.; Espín, J.C.; et al. One-year supplementation with a grape extract containing resveratrol modulates inflammatory-related microRNAs and cytokines expression in peripheral blood mononuclear cells of type 2 diabetes and hypertensive patients with coronary artery disease. Pharmacol. Res. 2013, 72, 69-82. [CrossRef] [PubMed]

115. Khodabandehloo, H.; Seyyedebrahimi, S.; Esfahani, E.N.; Razi, F.; Meshkani, R. Resveratrol supplementation decreases blood glucose without changing the circulating CD14. Nutr. Res. 2018, 54, 40-51. [CrossRef] [PubMed]

116. Haghighatdoost, F.; Hariri, M. Can resveratrol supplement change inflammatory mediators? A systematic review and meta-analysis on randomized clinical trials. Eur. J. Clin. Nutr. 2018. [CrossRef] [PubMed]

117. Kumar, A.; Sharma, S.S. NF-kappaB inhibitory action of resveratrol: A probable mechanism of neuroprotection in experimental diabetic neuropathy. Biochem. Biophys. Res. Commun. 2010, 394, 360-365. [CrossRef] [PubMed]

118. Truong, V.L.; Jun, M.; Jeong, W.S. Role of resveratrol in regulation of cellular defense systems against oxidative stress. Biofactors 2018, 44, 36-49. [CrossRef] [PubMed]

119. Ungvari, Z.; Labinskyy, N.; Mukhopadhyay, P.; Pinto, J.T.; Bagi, Z.; Ballabh, P.; Zhang, C.; Pacher, P.; Csiszar, A. Resveratrol attenuates mitochondrial oxidative stress in coronary arterial endothelial cells. Am. J. Physiol. Heart Circ. Physiol. 2009, 297, H1876-H1881. [CrossRef] [PubMed]

120. Chen, F.; Qian, L.H.; Deng, B.; Liu, Z.M.; Zhao, Y.; Le, Y.Y. Resveratrol protects vascular endothelial cells from high glucose-induced apoptosis through inhibition of NADPH oxidase activation-driven oxidative stress. CNS Neurosci. Ther. 2013, 19, 675-681. [CrossRef] [PubMed] 
121. Yun, J.M.; Chien, A.; Jialal, I.; Devaraj, S. Resveratrol up-regulates SIRT1 and inhibits cellular oxidative stress in the diabetic milieu: Mechanistic insights. J. Nutr. Biochem. 2012, 23, 699-705. [CrossRef] [PubMed]

122. Guo, S.; Yao, Q.; Ke, Z.; Chen, H.; Wu, J.; Liu, C. Resveratrol attenuates high glucose-induced oxidative stress and cardiomyocyte apoptosis through AMPK. Mol. Cell Endocrinol. 2015, 412, 85-94. [CrossRef] [PubMed]

123. Franco, J.G.; Lisboa, P.C.; Lima, N.S.; Amaral, T.A.; Peixoto-Silva, N.; Resende, A.C.; Oliveira, E.; Passos, M.C.; Moura, E.G. Resveratrol attenuates oxidative stress and prevents steatosis and hypertension in obese rats programmed by early weaning. J. Nutr. Biochem. 2013, 24, 960-966. [CrossRef] [PubMed]

124. Zhang, H.; Zhang, J.; Ungvari, Z.; Zhang, C. Resveratrol improves endothelial function: Role of TNF $\alpha$ and vascular oxidative stress. Arterioscler. Thromb. Vasc. Biol. 2009, 29, 1164-1171. [CrossRef] [PubMed]

125. Ungvari, Z.; Bagi, Z.; Feher, A.; Recchia, F.A.; Sonntag, W.E.; Pearson, K.; de Cabo, R.; Csiszar, A. Resveratrol confers endothelial protection via activation of the antioxidant transcription factor Nrf2. Am. J. Physiol. Heart Circ. Physiol. 2010, 299, H18-H24. [CrossRef] [PubMed]

126. Zhang, H.; Morgan, B.; Potter, B.J.; Ma, L.; Dellsperger, K.C.; Ungvari, Z.; Zhang, C. Resveratrol improves left ventricular diastolic relaxation in type 2 diabetes by inhibiting oxidative/nitrative stress: In vivo demonstration with magnetic resonance imaging. Am. J. Physiol. Heart Circ. Physiol. 2010, 299, H985-H994. [CrossRef] [PubMed]

127. Apostolidou, C.; Adamopoulos, K.; Iliadis, S.; Kourtidou-Papadeli, C. Alterations of antioxidant status in asymptomatic hypercholesterolemic individuals after resveratrol intake. Int. J. Food Sci. Nutr. 2015, 67, 541-552. [CrossRef] [PubMed]

128. De Groote, D.; Van Belleghem, K.; Devière, J.; Van Brussel, W.; Mukaneza, A.; Amininejad, L. Effect of the intake of resveratrol, resveratrol phosphate, and catechin-rich grape seed extract on markers of oxidative stress and gene expression in adult obese subjects. Ann. Nutr. Metab. 2012, 61, 15-24. [CrossRef] [PubMed]

129. Wang, H.L.; Gao, J.P.; Han, Y.L.; Xu, X.; Wu, R.; Gao, Y.; Cui, X.H. Comparative studies of polydatin and resveratrol on mutual transformation and antioxidative effect in vivo. Phytomedicine 2015, 22, 553-559. [CrossRef] [PubMed]

130. Hao, J.; Chen, C.; Huang, K.; Huang, J.; Li, J.; Liu, P.; Huang, H. Polydatin improves glucose and lipid metabolism in experimental diabetes through activating the Akt signaling pathway. Eur. J. Pharmacol. 2014, 745, 152-165. [CrossRef] [PubMed]

131. Wang, Y.; Ye, J.; Li, J.; Chen, C.; Huang, J.; Liu, P.; Huang, H. Polydatin ameliorates lipid and glucose metabolism in type 2 diabetes mellitus by downregulating proprotein convertase subtilisin/kexin type 9 (PCSK9). Cardiovasc. Diabetol. 2016, 15, 19. [CrossRef] [PubMed]

132. Zhao, X.J.; Yu, H.W.; Yang, Y.Z.; Wu, W.Y.; Chen, T.Y.; Jia, K.K.; Kang, L.L.; Jiao, R.Q.; Kong, L.D. Polydatin prevents fructose-induced liver inflammation and lipid deposition through increasing miR-200a to regulate Keap1/Nrf2 pathway. Redox. Biol. 2018, 18, 124-137. [CrossRef] [PubMed]

133. Eseberri, I.; Lasa, A.; Churruca, I.; Portillo, M.P. Resveratrol metabolites modify adipokine expression and secretion in 3T3-L1 pre-adipocytes and mature adipocytes. PLoS ONE 2013, 8, e63918. [CrossRef] [PubMed]

134. Lasa, A.; Churruca, I.; Eseberri, I.; Andrés-Lacueva, C.; Portillo, M.P. Delipidating effect of resveratrol metabolites in 3T3-L1 adipocytes. Mol. Nutr. Food Res. 2012, 56, 1559-1568. [CrossRef] [PubMed]

135. Hoshino, J.; Park, E.J.; Kondratyuk, T.P.; Marler, L.; Pezzuto, J.M.; van Breemen, R.B.; Mo, S.; Li, Y.; Cushman, M. Selective synthesis and biological evaluation of sulfate-conjugated resveratrol metabolites. J. Med. Chem. 2010, 53, 5033-5043. [CrossRef] [PubMed]

136. Schueller, K.; Pignitter, M.; Somoza, V. Sulfated and glucuronated trans-resveratrol metabolites regulate chemokines and sirtuin-1 expression in u-937 macrophages. J. Agric. Food Chem. 2015, 63, 6535-6545. [CrossRef] [PubMed]

137. Stivala, L.A.; Savio, M.; Carafoli, F.; Perucca, P.; Bianchi, L.; Maga, G.; Forti, L.; Pagnoni, U.M.; Albini, A.; Prosperi, E.; et al. Specific structural determinants are responsible for the antioxidant activity and the cell cycle effects of resveratrol. J. Biol. Chem. 2001, 276, 22586-22594. [CrossRef] [PubMed]

138. Azorín-Ortuño, M.; Yáñez-Gascón, M.J.; González-Sarrías, A.; Larrosa, M.; Vallejo, F.; Pallarés, F.J.; Lucas, R.; Morales, J.C.; Tomás-Barberán, F.A.; García-Conesa, M.T.; et al. Effects of long-term consumption of low doses of resveratrol on diet-induced mild hypercholesterolemia in pigs: A transcriptomic approach to disease prevention. J. Nutr. Biochem. 2012, 23, 829-837. [CrossRef] [PubMed] 
139. Aires, V.; Delmas, D.; Le Bachelier, C.; Latruffe, N.; Schlemmer, D.; Benoist, J.F.; Djouadi, F.; Bastin, J. Stilbenes and resveratrol metabolites improve mitochondrial fatty acid oxidation defects in human fibroblasts. Orphanet. J. Rare. Dis. 2014, 9, 79. [CrossRef] [PubMed]

140. Vogl, S.; Atanasov, A.G.; Binder, M.; Bulusu, M.; Zehl, M.; Fakhrudin, N.; Heiss, E.H.; Picker, P.; Wawrosch, C.; Saukel, J.; et al. The herbal drug melampyrum pratense 1. (koch): isolation and identification of its bioactive compounds targeting mediators of inflammation. Evid. Based Complem. Alternat. Med. 2013, 2013, 395316. [CrossRef] [PubMed]

141. Ito-Nagahata, T.; Kurihara, C.; Hasebe, M.; Ishii, A.; Yamashita, K.; Iwabuchi, M.; Sonoda, M.; Fukuhara, K.; Sawada, R.; Matsuoka, A.; et al. Stilbene analogs of resveratrol improve insulin resistance through activation of AMPK. Biosci. Biotechnol. Biochem. 2013, 77, 1229-1235. [CrossRef] [PubMed]

142. Carpéné, C.; Pejenaute, H.; Del Moral, R.; Boulet, N.; Hijona, E.; Andrade, F.; Villanueva-Millán, M.J.; Aguirre, L.; Arbones-Mainar, J.M. The dietary antioxidant piceatannol inhibits adipogenesis of human adipose mesenchymal stem cells and limits glucose transport and lipogenic activities in adipocytes. Int. J. Mol. Sci. 2018. [CrossRef] [PubMed]

143. Les, F.; Deleruyelle, S.; Cassagnes, L.E.; Boutin, J.A.; Balogh, B.; Arbones-Mainar, J.M.; Biron, S.; Marceau, P.; Richard, D.; Nepveu, F.; et al. Piceatannol and resveratrol share inhibitory effects on hydrogen peroxide release, monoamine oxidase and lipogenic activities in adipose tissue, but differ in their antilipolytic properties. Chem. Biol. Interact. 2016, 258, 115-125. [CrossRef] [PubMed]

144. Uchida-Maruki, H.; Inagaki, H.; Ito, R.; Kurita, I.; Sai, M.; Ito, T. Piceatannol lowers the blood glucose level in diabetic mice. Biol. Pharm. Bull. 2015, 38, 629-633. [CrossRef] [PubMed]

145. Setoguchi, Y.; Oritani, Y.; Ito, R.; Inagaki, H.; Maruki-Uchida, H.; Ichiyanagi, T.; Ito, T. Absorption and metabolism of piceatannol in rats. J. Agric. Food Chem. 2014, 62, 2541-2548. [CrossRef] [PubMed]

146. Eräsalo, H.; Hämäläinen, M.; Leppänen, T.; Mäki-Opas, I.; Laavola, M.; Haavikko, R.; Yli-Kauhaluoma, J.; Moilanen, E. Natural stilbenoids have anti-inflammatory properties in vivo and down-regulate the production of inflammatory mediators no, il6, and mcp1 possibly in a pi3k/akt-dependent manner. J. Nat. Prod. 2018, 81, 1131-1142. [CrossRef] [PubMed]

147. Clemente, J.C.; Ursell, L.K.; Parfrey, L.W.; Knight, R. The impact of the gut microbiota on human health: An integrative view. Cell 2012, 148, 1258-1270. [CrossRef] [PubMed]

148. Lankelma, J.M.; Nieuwdorp, M.; de Vos, W.M.; Wiersinga, W.J. The gut microbiota in internal medicine: Implications for health and disease. Neth. J. Med. 2015, 73, 61-68. [PubMed]

149. Zhao, L. The gut microbiota and obesity: From correlation to causality. Nat. Rev. Microbiol. 2013, 11, 639-647. [CrossRef] [PubMed]

150. De Vos, W.M.; de Vos, E.A. Role of the intestinal microbiome in health and disease: From correlation to causation. Nutr. Rev. 2012. [CrossRef] [PubMed]

151. Tilg, H.; Adolph, T.E.; Gerner, R.R.; Moschen, A.R. The intestinal microbiota in colorectal cancer. Cancer Cell 2018, 33, 954-964. [CrossRef] [PubMed]

152. Li, J.; Zhao, F.; Wang, Y.; Chen, J.; Tao, J.; Tian, G.; Wu, S.; Liu, W.; Cui, Q.; Geng, B.; et al. Gut microbiota dysbiosis contributes to the development of hypertension. Microbiome 2017, 5, 14. [CrossRef] [PubMed]

153. Tilg, H.; Moschen, A.R. Microbiota and diabetes: An evolving relationship. Gut 2014, 63, $1513-1521$. [CrossRef] [PubMed]

154. Cani, P.D. Gut microbiota-At the intersection of everything? Nat. Rev. Gastroenterol. Hepatol. 2017, 14, 321-322. [CrossRef] [PubMed]

155. O'Hara, A.M.; Shanahan, F. The gut flora as a forgotten organ. EMBO Rep. 2006, 7, 688-693. [CrossRef] [PubMed]

156. Den Besten, G.; van Eunen, K.; Groen, A.K.; Venema, K.; Reijngoud, D.J.; Bakker, B.M. The role of short-chain fatty acids in the interplay between diet, gut microbiota, and host energy metabolism. J. Lipid Res. 2013, 54, 2325-2340. [CrossRef] [PubMed]

157. Remely, M.; Aumueller, E.; Merold, C.; Dworzak, S.; Hippe, B.; Zanner, J.; Pointner, A.; Brath, H.; Haslberger, A.G. Effects of short chain fatty acid producing bacteria on epigenetic regulation of FFAR3 in type 2 diabetes and obesity. Gene 2014, 537, 85-92. [CrossRef] [PubMed]

158. Thursby, E.; Juge, N. Introduction to the human gut microbiota. Biochem. J. 2017, 474, 1823-1836. [CrossRef] [PubMed] 
159. Luckey, T.D. Introduction to intestinal microecology. Am. J. Clin. Nutr. 1972, 25, 1292-1294. [CrossRef] [PubMed]

160. Sender, R.; Fuchs, S.; Milo, R. Are we really vastly outnumbered? revisiting the ratio of bacterial to host cells in humans. Cell 2016, 164, 337-340. [CrossRef] [PubMed]

161. Integrative HMP (iHMP) Research Network Consortium. The Integrative Human Microbiome Project: Dynamic analysis of microbiome-host omics profiles during periods of human health and disease. Cell Host. Microbe. 2014, 16, 276-289. [CrossRef] [PubMed]

162. Arumugam, M.; Raes, J.; Pelletier, E.; Le Paslier, D.; Yamada, T.; Mende, D.R.; Fernandes, G.R.; Tap, J.; Bruls, T.; Batto, J.M.; et al. Enterotypes of the human gut microbiome. Nature 2011, 473, 174-180. [CrossRef] [PubMed]

163. Le Chatelier, E.; Nielsen, T.; Qin, J.; Prifti, E.; Hildebrand, F.; Falony, G.; Almeida, M.; Arumugam, M.; Batto, J.M.; Kennedy, S.; et al. Richness of human gut microbiome correlates with metabolic markers. Nature 2013, 500, 541-546. [CrossRef] [PubMed]

164. Wen, L.; Duffy, A. Factors influencing the gut microbiota, inflammation, and type 2 diabetes. J. Nutr. 2017, 147, 1468S-1475S. [CrossRef] [PubMed]

165. Dethlefsen, L.; Relman, D.A. Incomplete recovery and individualized responses of the human distal gut microbiota to repeated antibiotic perturbation. Proc. Natl. Acad. Sci. USA 2011, 108, 4554-4561. [CrossRef] [PubMed]

166. Knights, D.; Ward, T.L.; McKinlay, C.E.; Miller, H.; Gonzalez, A.; McDonald, D.; Knight, R. Rethinking "enterotypes". Cell Host. Microbe. 2014, 16, 433-437. [CrossRef] [PubMed]

167. Cani, P.D.; Delzenne, N.M. The role of the gut microbiota in energy metabolism and metabolic disease. Curr. Pharm. Des. 2009, 15, 1546-1558. [CrossRef] [PubMed]

168. Scheithauer, T.P.; Dallinga-Thie, G.M.; de Vos, W.M.; Nieuwdorp, M.; van Raalte, D.H. Causality of small and large intestinal microbiota in weight regulation and insulin resistance. Mol. Metab. 2016, 5, 759-770. [CrossRef] [PubMed]

169. Larsen, N.; Vogensen, F.K.; van den Berg, F.W.; Nielsen, D.S.; Andreasen, A.S.; Pedersen, B.K.; Al-Soud, W.A.; Sorensen, S.J.; Hansen, L.H.; Jakobsen, M. Gut microbiota in human adults with type 2 diabetes differs from non-diabetic adults. PLoS ONE 2010, 5, e9085. [CrossRef] [PubMed]

170. Million, M.; Lagier, J.C.; Yahav, D.; Paul, M. Gut bacterial microbiota and obesity. Clin. Microbiol. Infect. 2013, 19, 305-313. [CrossRef] [PubMed]

171. Turnbaugh, P.J.; Hamady, M.; Yatsunenko, T.; Cantarel, B.L.; Duncan, A.; Ley, R.E.; Sogin, M.L.; Jones, W.J.; Roe, B.A.; Affourtit, J.P.; et al. A core gut microbiome in obese and lean twins. Nature 2009, 457, 480-484. [CrossRef] [PubMed]

172. Plovier, H.; Cani, P.D. Microbial impact on host metabolism: Opportunities for novel treatments of nutritional disorders? Microbiol. Spectr. 2017. [CrossRef] [PubMed]

173. Karlsson, F.H.; Tremaroli, V.; Nookaew, I.; Bergstrom, G.; Behre, C.J.; Fagerberg, B.; Nielsen, J.; Backhed, F. Gut metagenome in European women with normal, impaired and diabetic glucose control. Nature 2013, 498, 99-103. [CrossRef] [PubMed]

174. Turnbaugh, P.J.; Ridaura, V.K.; Faith, J.J.; Rey, F.E.; Knight, R.; Gordon, J.I. The effect of diet on the human gut microbiome: A metagenomic analysis in humanized gnotobiotic mice. Sci. Transl. Med. 2009. [CrossRef] [PubMed]

175. Turnbaugh, P.J.; Gordon, J.I. The core gut microbiome, energy balance and obesity. J. Physiol. 2009, 587, 4153-4158. [CrossRef] [PubMed]

176. Mahowald, M.A.; Rey, F.E.; Seedorf, H.; Turnbaugh, P.J.; Fulton, R.S.; Wollam, A.; Shah, N.; Wang, C.; Magrini, V.; Wilson, R.K.; et al. Characterizing a model human gut microbiota composed of members of its two dominant bacterial phyla. Proc. Natl. Acad. Sci. USA 2009, 106, 5859-5864. [CrossRef] [PubMed]

177. Ley, R.E.; Backhed, F.; Turnbaugh, P.; Lozupone, C.A.; Knight, R.D.; Gordon, J.I. Obesity alters gut microbial ecology. Proc. Natl. Acad. Sci. USA 2005, 102, 11070-11075. [CrossRef] [PubMed]

178. Ley, R.E.; Turnbaugh, P.J.; Klein, S.; Gordon, J.I. Microbial ecology: Human gut microbes associated with obesity. Nature 2006, 444, 1022-1023. [CrossRef] [PubMed]

179. Rawls, J.F.; Mahowald, M.A.; Ley, R.E.; Gordon, J.I. Reciprocal gut microbiota transplants from zebrafish and mice to germ-free recipients reveal host habitat selection. Cell 2006, 127, 423-433. [CrossRef] [PubMed] 
180. Rabot, S.; Membrez, M.; Bruneau, A.; Gerard, P.; Harach, T.; Moser, M.; Raymond, F.; Mansourian, R.; Chou, C.J. Germ-free C57BL/6J mice are resistant to high-fat-diet-induced insulin resistance and have altered cholesterol metabolism. FASEB J. 2010, 24, 4948-4959. [CrossRef] [PubMed]

181. Caricilli, A.M.; Picardi, P.K.; de Abreu, L.L.; Ueno, M.; Prada, P.O.; Ropelle, E.R.; Hirabara, S.M.; Castoldi, A.; Vieira, P.; Camara, N.O.; et al. Gut microbiota is a key modulator of insulin resistance in TLR 2 knockout mice. PLoS Biol. 2011, 9, e1001212. [CrossRef] [PubMed]

182. Olefsky, J.M.; Glass, C.K. Macrophages, inflammation, and insulin resistance. Annu. Rev. Physiol. 2010, 72, 219-246. [CrossRef] [PubMed]

183. Osborn, O.; Olefsky, J.M. The cellular and signaling networks linking the immune system and metabolism in disease. Nat. Med. 2012, 18, 363-374. [CrossRef] [PubMed]

184. Cani, P.D.; Delzenne, N.M. Involvement of the gut microbiota in the development of low grade inflammation associated with obesity: Focus on this neglected partner. Acta. Gastroenterol. Belg. 2010, 73, 267-269. [PubMed]

185. Cani, P.D.; Amar, J.; Iglesias, M.A.; Poggi, M.; Knauf, C.; Bastelica, D.; Neyrinck, A.M.; Fava, F.; Tuohy, K.M.; Chabo, C.; et al. Metabolic endotoxemia initiates obesity and insulin resistance. Diabetes 2007, 56, 1761-1772. [CrossRef] [PubMed]

186. Luche, E.; Cousin, B.; Garidou, L.; Serino, M.; Waget, A.; Barreau, C.; Andre, M.; Valet, P.; Courtney, M.; Casteilla, L.; et al. Metabolic endotoxemia directly increases the proliferation of adipocyte precursors at the onset of metabolic diseases through a CD14-dependent mechanism. Mol. Metab. 2013, 2, 281-291. [CrossRef] [PubMed]

187. Pussinen, P.J.; Havulinna, A.S.; Lehto, M.; Sundvall, J.; Salomaa, V. Endotoxemia is associated with an increased risk of incident diabetes. Diabetes Care 2011, 34, 392-397. [CrossRef] [PubMed]

188. Cani, P.D.; Osto, M.; Geurts, L.; Everard, A. Involvement of gut microbiota in the development of low-grade inflammation and type 2 diabetes associated with obesity. Gut Microbes 2012, 3, 279-288. [CrossRef] [PubMed]

189. Salonen, A.; de Vos, W.M. Impact of diet on human intestinal microbiota and health. Annu. Rev. Food Sci. Technol. 2014, 5, 239-262. [CrossRef] [PubMed]

190. Sonnenburg, J.L.; Backhed, F. Diet-microbiota interactions as moderators of human metabolism. Nature 2016, 535, 56-64. [CrossRef] [PubMed]

191. Cani, P.D.; Everard, A. Talking microbes: When gut bacteria interact with diet and host organs. Mol. Nutr. Food Res. 2016, 60, 58-66. [CrossRef] [PubMed]

192. Yatsunenko, T.; Rey, F.E.; Manary, M.J.; Trehan, I.; Dominguez-Bello, M.G.; Contreras, M.; Magris, M.; Hidalgo, G.; Baldassano, R.N.; Anokhin, A.P.; et al. Human gut microbiome viewed across age and geography. Nature 2012, 486, 222-227. [CrossRef] [PubMed]

193. De Filippo, C.; Cavalieri, D.; Di Paola, M.; Ramazzotti, M.; Poullet, J.B.; Massart, S.; Collini, S.; Pieraccini, G.; Lionetti, P. Impact of diet in shaping gut microbiota revealed by a comparative study in children from Europe and rural Africa. Proc. Natl. Acad. Sci. USA 2010, 107, 14691-14696. [CrossRef] [PubMed]

194. Faith, J.J.; Guruge, J.L.; Charbonneau, M.; Subramanian, S.; Seedorf, H.; Goodman, A.L.; Clemente, J.C.; Knight, R.; Heath, A.C.; Leibel, R.L.; et al. The long-term stability of the human gut microbiota. Science 2013, 341, 1237439. [CrossRef] [PubMed]

195. David, L.A.; Maurice, C.F.; Carmody, R.N.; Gootenberg, D.B.; Button, J.E.; Wolfe, B.E.; Ling, A.V.; Devlin, A.S.; Varma, Y.; Fischbach, M.A.; et al. Diet rapidly and reproducibly alters the human gut microbiome. Nature 2014, 505, 559-563. [CrossRef] [PubMed]

196. Wu, G.D.; Chen, J.; Hoffmann, C.; Bittinger, K.; Chen, Y.Y.; Keilbaugh, S.A.; Bewtra, M.; Knights, D.; Walters, W.A.; Knight, R.; et al. Linking long-term dietary patterns with gut microbial enterotypes. Science 2011, 334, 105-108. [CrossRef] [PubMed]

197. Rabot, S.; Membrez, M.; Blancher, F.; Berger, B.; Moine, D.; Krause, L.; Bibiloni, R.; Bruneau, A.; Gerard, P.; Siddharth, J.; et al. High fat diet drives obesity regardless the composition of gut microbiota in mice. Sci. Rep. 2016, 6, 32484. [CrossRef] [PubMed]

198. Ramirez-Farias, C.; Slezak, K.; Fuller, Z.; Duncan, A.; Holtrop, G.; Louis, P. Effect of inulin on the human gut microbiota: Stimulation of Bifidobacterium adolescentis and Faecalibacterium prausnitzii. Br. J. Nutr. 2009, 101, 541-550. [CrossRef] [PubMed] 
199. Chaplin, A.; Parra, P.; Laraichi, S.; Serra, F.; Palou, A. Calcium supplementation modulates gut microbiota in a prebiotic manner in dietary obese mice. Mol. Nutr. Food Res. 2016, 60, 468-480. [CrossRef] [PubMed]

200. Cote, C.D.; Rasmussen, B.A.; Duca, F.A.; Zadeh-Tahmasebi, M.; Baur, J.A.; Daljeet, M.; Breen, D.M.; Filippi, B.M.; Lam, T.K. Resveratrol activates duodenal Sirt1 to reverse insulin resistance in rats through a neuronal network. Nat. Med. 2015, 21, 498-505. [CrossRef] [PubMed]

201. Sung, M.M.; Kim, T.T.; Denou, E.; Soltys, C.M.; Hamza, S.M.; Byrne, N.J.; Masson, G.; Park, H.; Wishart, D.S.; Madsen, K.L.; et al. Improved glucose homeostasis in obese mice treated with resveratrol is associated with alterations in the gut microbiome. Diabetes 2017, 66, 418-425. [CrossRef] [PubMed]

202. Kim, T.T.; Parajuli, N.; Sung, M.M.; Bairwa, S.C.; Levasseur, J.; Soltys, C.M.; Wishart, D.S.; Madsen, K.; Schertzer, J.D.; Dyck, J.R.B. Fecal transplant from resveratrol-fed donors improves glycaemia and cardiovascular features of the metabolic syndrome in mice. Am. J. Physiol. Endocrinol. Metab. 2018. [CrossRef] [PubMed]

203. Chen, M.L.; Yi, L.; Zhang, Y.; Zhou, X.; Ran, L.; Yang, J.; Zhu, J.D.; Zhang, Q.Y.; Mi, M.T. Resveratrol Attenuates Trimethylamine-N-Oxide (TMAO)-Induced Atherosclerosis by Regulating TMAO Synthesis and Bile Acid Metabolism via Remodeling of the Gut Microbiota. MBio 2016, 7, e02210-15. [CrossRef] [PubMed]

204. Sung, M.M.; Byrne, N.J.; Robertson, I.M.; Kim, T.T.; Samokhvalov, V.; Levasseur, J.; Soltys, C.L.; Fung, D.; Tyreman, N.; Denou, E.; et al. Resveratrol improves exercise performance and skeletal muscle oxidative capacity in heart failure. Am. J. Physiol. Heart Circ. Physiol. 2017, 312, H842-H853. [CrossRef] [PubMed]

205. Jung, M.J.; Lee, J.; Shin, N.R.; Kim, M.S.; Hyun, D.W.; Yun, J.H.; Kim, P.S.; Whon, T.W.; Bae, J.W. Chronic repression of mtor complex 2 induces changes in the gut microbiota of diet-induced obese mice. Sci. Rep. 2016, 6, 30887. [CrossRef] [PubMed]

206. Tung, Y.C.; Lin, Y.H.; Chen, H.J.; Chou, S.C.; Cheng, A.C.; Kalyanam, N.; Ho, C.T.; Pan, M.H. Piceatannol Exerts Anti-Obesity Effects in C57BL/6 Mice through Modulating Adipogenic Proteins and Gut Microbiota. Molecules 2016. [CrossRef] [PubMed]

207. Qiao, Y.; Sun, J.; Xia, S.; Tang, X.; Shi, Y.; Le, G. Effects of resveratrol on gut microbiota and fat storage in a mouse model with high-fat-induced obesity. Food Funct. 2014, 5, 1241-1249. [CrossRef] [PubMed]

208. Dao, T.M.; Waget, A.; Klopp, P.; Serino, M.; Vachoux, C.; Pechere, L.; Drucker, D.J.; Champion, S.; Barthelemy, S.; Barra, Y.; et al. Resveratrol increases glucose induced GLP-1 secretion in mice: A mechanism which contributes to the glycemic control. PLOS ONE 2011, 6, e20700. [CrossRef] [PubMed]

209. Zhao, L.; Zhang, Q.; Ma, W.; Tian, F.; Shen, H.; Zhou, M. A combination of quercetin and resveratrol reduces obesity in high-fat diet-fed rats by modulation of gut microbiota. Food Funct. 2017, 8, 4644-4656. [CrossRef] [PubMed]

210. Hijona, E.; Aguirre, L.; Perez-Matute, P.; Villanueva-Millan, M.J.; Mosqueda-Solis, A.; Hasnaoui, M.; Nepveu, F.; Senard, J.M.; Bujanda, L.; Aldamiz-Echevarria, L.; et al. Limited beneficial effects of piceatannol supplementation on obesity complications in the obese Zucker rat: Gut microbiota, metabolic, endocrine, and cardiac aspects. J. Physiol. Biochem. 2016, 72, 567-582. [CrossRef] [PubMed]

211. Etxeberria, U.; Arias, N.; Boque, N.; Macarulla, M.T.; Portillo, M.P.; Martinez, J.A.; Milagro, F.I. Reshaping faecal gut microbiota composition by the intake of trans-resveratrol and quercetin in high-fat sucrose diet-fed rats. J. Nutr. Biochem. 2015, 26, 651-660. [CrossRef] [PubMed]

212. Tain, Y.L.; Lee, W.C.; Wu, K.L.H.; Leu, S.; Chan, J.Y.H. Resveratrol prevents the development of hypertension programmed by maternal plus post-weaning high-fructose consumption through modulation of oxidative stress, nutrient-sensing signals, and gut microbiota. Mol. Nutr. Food Res. 2018. [CrossRef] [PubMed]

213. Most, J.; Penders, J.; Lucchesi, M.; Goossens, G.H.; Blaak, E.E. Gut microbiota composition in relation to the metabolic response to 12-week combined polyphenol supplementation in overweight men and women. Eur. J. Clin. Nutr. 2017, 71, 1040-1045. [CrossRef] [PubMed]

214. Samson, S.L.; Garber, A.J. Metabolic syndrome. Endocrinol. Metab. Clin. N. Am. 2014, 43, 1-23. [CrossRef] [PubMed]

215. Piotrowska, H.; Kucinska, M.; Murias, M. Biological activity of piceatannol: Leaving the shadow of resveratrol. Mutat. Res. 2012, 750, 60-82. [CrossRef] [PubMed]

216. Ryu, D.; Mouchiroud, L.; Andreux, P.A.; Katsyuba, E.; Moullan, N.; Nicolet-Dit-Félix, A.A.; Williams, E.G.; Jha, P.; Lo Sasso, G.; Huzard, D.; et al. Urolithin A induces mitophagy and prolongs lifespan in C. elegans and increases muscle function in rodents. Nat. Med. 2016, 22, 879-888. [CrossRef] [PubMed] 
217. Li, J.; Riaz Rajoka, M.S.; Shao, D.; Jiang, C.; Jin, M.; Huang, Q.; Yang, H.; Shi, J. Strategies to increase the efficacy of using gut microbiota for the modulation of obesity. Obes. Rev. 2017, 18, 1260-1271. [CrossRef] [PubMed]

218. Nohr, M.K.; Kroager, T.P.; Sanggaard, K.W.; Knudsen, A.D.; Stensballe, A.; Enghild, J.J.; Olholm, J.; Richelsen, B.; Pedersen, S.B. SILAC-MS Based Characterization of LPS and Resveratrol Induced Changes in Adipocyte Proteomics-Resveratrol as Ameliorating Factor on LPS Induced Changes. PLoS ONE 2016, 11, e0159747. [CrossRef] [PubMed]

219. Etxeberria, U.; Castilla-Madrigal, R.; Lostao, M.P.; Martínez, J.A.; Milagro, F.I. Trans-resveratrol induces a potential anti-lipogenic effect in lipopolysaccharide-stimulated enterocytes. Cell Mol. Biol. 2015, 61, 9-16. [PubMed]

220. Elovaara, H.; Huusko, T.; Maksimow, M.; Elima, K.; Yegutkin, G.G.; Skurnik, M.; Dobrindt, U.; Siitonen, A.; McPherson, M.J.; Salmi, M.; et al. Primary Amine Oxidase of Escherichia coli Is a Metabolic Enzyme that Can Use a Human Leukocyte Molecule as a Substrate. PLoS ONE 2015, 10, e0142367. [CrossRef] [PubMed]

(C) 2018 by the authors. Licensee MDPI, Basel, Switzerland. This article is an open access article distributed under the terms and conditions of the Creative Commons Attribution (CC BY) license (http://creativecommons.org/licenses/by/4.0/). 